\title{
AN ANALYSIS OF ENCYCLOPAEDIA CITATIONS IN UNIVERSITY OF AUCKLAND DOCTOR OF PHILOSOPHY DISSERTATIONS (2007 AND 2008)
}

by

\section{WENDY YEE TONG}

Submitted to the School of Information Management, Victoria University of Wellington in partial fulfilment of the requirements for the degree of Master of Library and Information Studies

\section{FEBRUARY 2010}




\section{Acknowledgements}

I would like to thank my supervisor, Lynley Stone, Senior Tutor (Auckland), School of Information Management, for all her time, support and advice. Without her offers to read my drafts and valuable suggestions to improve my work, this project could not have been completed.

I am also grateful to Alastair Smith, Senior Lecturer, School of Information Management, for his permission to use the original topic idea.

Last, but not least, thank you to my husband Jeff, and children Jordan and Alexander; without your financial support and constant encouragement over the last two years, furthering my education would not have been possible. 


\section{Table of Contents}

ABSTRACT

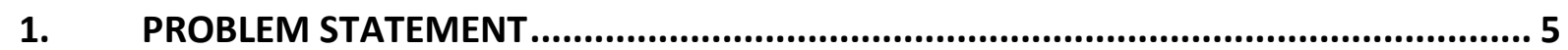

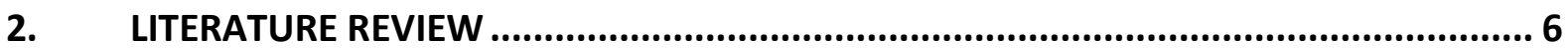

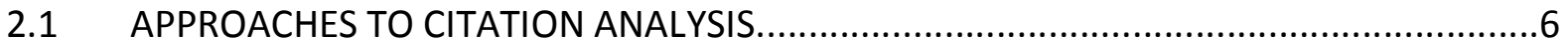

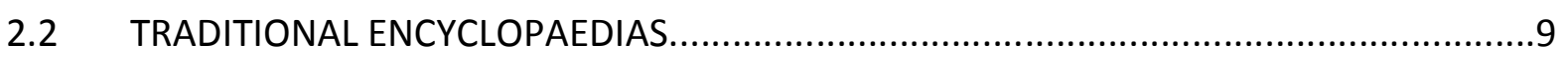

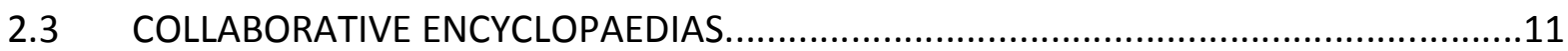

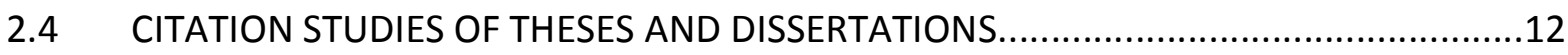

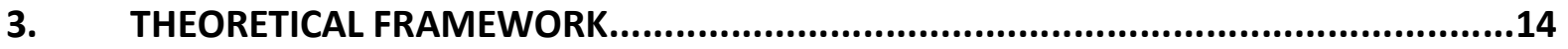

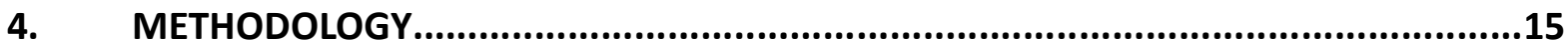

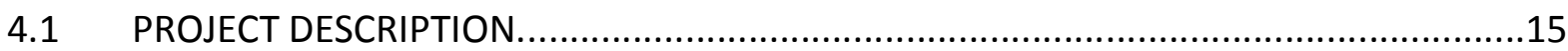

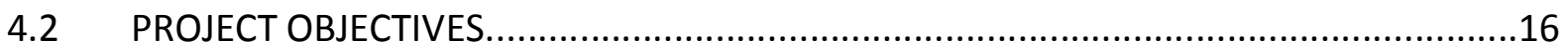

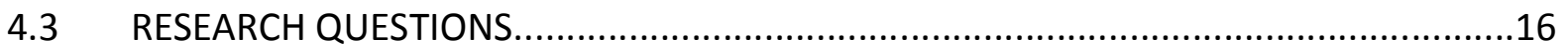

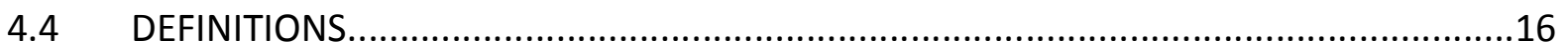

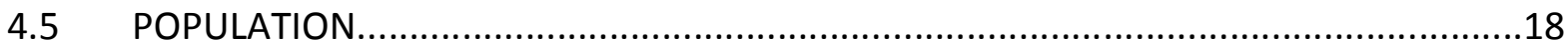

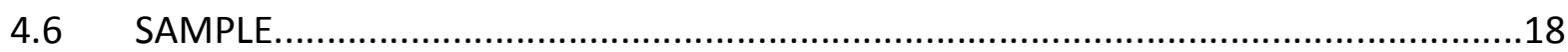

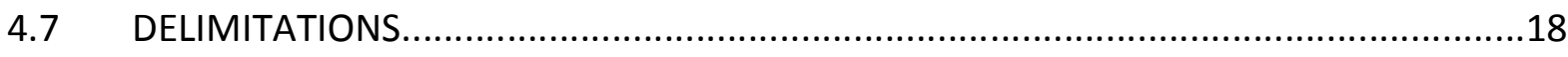

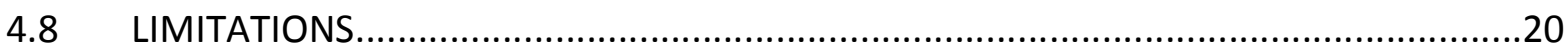

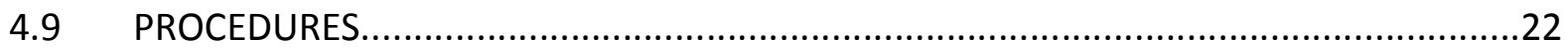

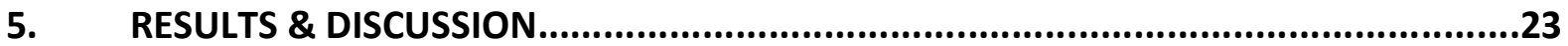

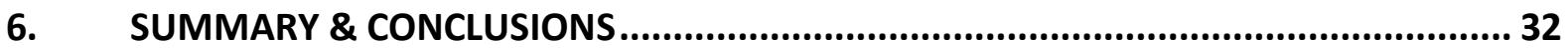

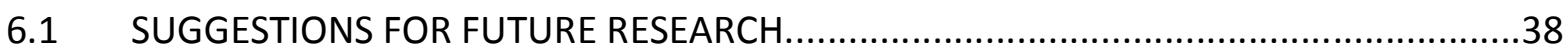

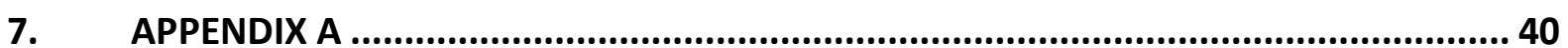

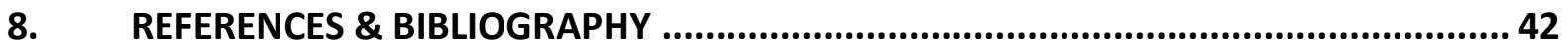

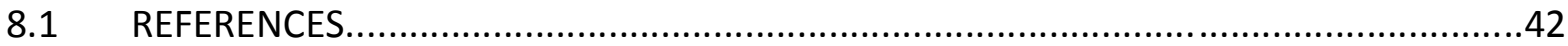

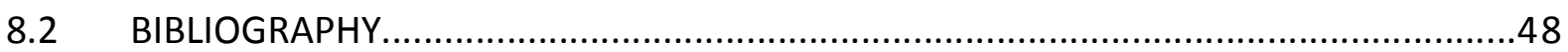




\section{ABSTRACT}

It is currently unknown to what extent encyclopaedias are cited in academic research in New Zealand. To provide preliminary findings on the use of encyclopaedias in university research and offer some evidence relating to the use of collaborative encyclopaedias in academic research, a quantitative empirical study of citations of encyclopaedias in 147 Doctor of Philosophy (PhD) Dissertations from the University of Auckland was made. Results included finding citations to encyclopaedias made up a very small ( $n=23$, or $0.1 \%$ in $2007 ; n=62$, or $0.3 \%$ in 2008 ) proportion of total citations. Of these, traditional style encyclopaedias were more frequently $(61 \%)$ used than collaborative (39\%) style encyclopaedias such as Wikipedia and the Encyclopaedia of Philosophy of Education. Wikipedia, a general, collaborative, and on-line format encyclopaedia, received the highest number of citations ( $n=32$ ). By subject, Computer Science and Statistics listed the highest number of 14 citations to Wikipedia; Engineering (Software, Mechanical and Electrical and Electronic) had 8 Wikipedia citations; English, French, Political Studies and Theology received 9 citations; and Nursing included one citation to Wikipedia. With the widely known concerns expressed about the suitability of citing Wikipedia at any level of academic research, it is surprising that this study found (albeit small) a measurable level of citations to Wikipedia in PhD dissertations in New Zealand.

The results of this study may be useful to university librarians and faculties in training students before they begin research for higher degrees.

Keywords: encyclopaedia, citations, collaborative, academic research. 


\section{PROBLEM STATEMENT}

Encyclopaedias are a key component of the general and subject reference collections in academic libraries, but it is unknown to what extent they are cited in academic research in New Zealand.

Traditionally, encyclopaedias were summaries of current knowledge (Kister, 1994, p. 3), and were written by subject experts and controlled by identifiable editorial management.

Academic libraries hold printed copies or subscribe to electronic versions of encyclopaedias, which may be either general in focus or provide in-depth information on a specific topic for users (Cassell \& Hiremath, 2006a, pp. 70, 83), for example, an article on computer ethics and intelligent technologies ("Computer ethics and intelligent technologies," 2008, Encyclopedia of Information Ethics and Security). The levels of encyclopaedia usage have not been the main focus in previous citation studies but available figures, for example, 1.14\% of citations in Master of Library and Information Science dissertations ( $n=40)$ from the period 2000-2005 at the University of Malaya (Yeap \& Kiran, 2008, p. 33), indicate a very low rate. This raises questions such as whether encyclopaedias are regarded as irrelevant and therefore not used, or are consulted but uncited, or even question users' ability to seek out a wide range of sources in research. It would appear that little is known about how encyclopaedias are used, or the extent and reasons for their use. Citation analysis may provide a starting point to obtain some knowledge about the use of encyclopaedias in university research, which could be followed by a qualitative study that explores how researchers use encyclopaedias. The results of this study may therefore assist librarians in training users and in promoting collection resources.

Since the advent of online collaborative encyclopaedias, such as Wikipedia (Wikipedia Foundation, 2009), containing information whose validity and reliability cannot be proven 
through either a peer review process or recognized editorial management, there has been concern (Gorman, 2007; Santana \& Woods, 2009a; Svoboda, 2006; Waters, 2007) that these encyclopaedias are cited in university research. These concerns result from Wikipedia's articles which are written by anonymous authors and edited by people of unknown qualifications and credentials; and articles which are often written without the inclusion of supporting references, and which, when corrected, can be changed to be misleading by people with agendas. Without this background knowledge, articles cannot easily be verified as reliable and accurate, with the latter qualities being essential components in university research.

To provide preliminary findings on the use of encyclopaedias in university research, the outcome of which may be useful to librarians teaching information literacy, and offer some evidence relating to the use of collaborative encyclopaedias in academic research in New Zealand, this research project will conduct a comparative study of citations of encyclopaedias in Doctor of Philosophy (PhD) Dissertations submitted in 2007 and 2008 to the University of Auckland.

\section{LITERATURE REVIEW}

\subsection{Approaches to Citation Analysis}

Garfield (1996) provides the basis of the normative theory of citation, which forms a part of the theoretical framework of this research, with his suggestion that there are fifteen main reasons for citations:

1. Paying homage to pioneers.

2. Giving credit for related work (homage to peers). 
3. Identifying methodology, equipment, etc.

4. Providing background reading.

5. Correcting one's own work.

6. Correcting the work of others.

7. Criticizing previous work.

8. Substantiating claims.

9. Alerting researchers to forthcoming work.

10. Providing leads to poorly disseminated, poorly indexed, or uncited work.

11. Authenticating data and classes of fact - physical constants, etc

12. Identifying original publications in which an idea or concept was discussed.

13. Identifying the original publication describing an eponymic concept or term as, e.g., Hodgkin's disease, Pareto's Law, Friedel-crafts Reaction, etc.

14. Disclaiming work or ideas of others (negative claims).

15. Disputing priority claims of others (negative homage)

(Garfield, 1996, pp. 451-452)

However, social constructivist theorists claim social ulterior motives and biased influences such as reward (Kaplan, 1965, p. 181), persuasion by citing authoritative peers, to illustrate the importance of results compared to current research, to fill a knowledge gap (Gilbert, 1977, pp. 115-117), distinction of degree (those graduating with "cum laude" honours are 
more likely to be cited, Van Raan, 1998, p. 132), "hat-tipping, premeditation, conspiratorial cross-referencing, and political considerations" (Thorne, 1977, pp. 1159-1160) are more likely to influence citation behaviour.

Cozzens (1989) advocates a more 'multidimensional' (Camacho-Minano \& Nunez-Nickel, 2009$, p. 755$)$ approach that combines the two theories with common factors: quality and importance from the social constructivist side, and relevance, utility and influence from the normative part (Cozzens, 1989, p. 441). Other advocates (Baldi, 1998b; Van der Veer Martens \& Goodrum, 2006; Van Raan, 1998) tend to agree the motivations for citing behaviour are interrelated and may range between positive, negative, functional and control reasons, for example: most relevant work on subject, physical accessibility, reviewer's request, article size (Baldi, 1998a; Bonzi \& Snyder, 1991; Harwood, 2008; Liu, 1997).

In addition to the three main citation theories, there are other beliefs or laws that may be used when interpreting bibliometric studies: the Matthew effect (Merton, 1968, pp. 5663), a derivative of the social constructivist 'reward' system, where authors, already well known, tend to be cited more often than less recognized authors in the same field regardless of source accessibility (Beck \& Manuel, 2008, p. 187); publication bias, that occurs when research articles which are more positive and significant tend to be published (Beck \& Manuel, 2008, p. 187); Lotka's Law (Hertzel, 2003, pp. 303 - 306), which deems a small proportion of authors in a field of study tend to produce a large number of publications (Borgman \& Furner, 2002, p. 49), which increases their chances of being cited than the larger proportion of authors who may only have published once (Beck \& Manuel, 2008, p. 187); and Bradford's Law (Hertzel, 2003, pp. 306 - 311) relates to the trend that a 
small number of journals in a field of study tends to publish almost a third of all articles, which results in citations and library holdings concentrating on these journals (Beck \& Manuel, 2008, p. 188).

Although the normative, social constructivist, and multi-dimensional citation theories, and the bibliometric 'laws' have often been used to analyse article citations in journals, they have not been identified in this paper's literature search as having been used to examine citations to encyclopaedias, whether general or discipline specific. The multi-dimensional approach is the most probable framework for the citation of encyclopaedias as it contains the more varied reasons to explain citation behaviour, but the normative and social constructivist factors of quality, importance, relevance and utility remain strong influences. Factors which may affect the citation of encyclopaedias include their reputation, editorial policies, language, content quality and currency, accessibility of medium (online or printed), knowledge of their range of content, and even the citer's level of information literacy (as defined in Cassell \& Hiremath, 2006b, pp. 273-276). It is uncertain that the bibliometric 'laws' can be used to analyse the citation of encyclopaedias because this study will be more an 'evaluative literature usage count' (Hertzel, 2003, p. 296) of citations, than a study of literature within a discipline with time or geographic variables.

\subsection{Traditional Encyclopaedias}

The limited amount of literature available about traditional encyclopaedias discusses their continued role and changing expectations in providing information. Crothers (2008) queries whether they should be regarded as part of academic literature and cited in research articles, believing they are more 'archival' and 'textbook' than academic research ( $p .175)$. He also raises issues such as the currency of information in printed versions, quality control 
in the range and balance of topics covered, classification framework, writing style, and authoritativeness (p. 177). The future of similar anthologies is also raised by Raven and Goldman (2007) who discuss whether the price of providing additional data and hyperlinks will undermine traditional articles in the Oxford Dictionary of National Biography but conclude that they may be essential to its future survival (pp. 1005-1006).

However, contrary to some of the above criticisms, traditional encyclopaedias are changing to include primary research, are increasingly available online (Maron \& Smith, 2009, Types of digital scholarly resources), and there are growing numbers of specialised encyclopaedias such as the printed World Encyclopedia of Political Systems and Parties, the Encyclopedia of American Foreign Policy, and the online Sage Encyclopedia of Social Science Research Methods.

The issue of currency of information, particularly in printed editions (Crothers, 2008, p. 175) is resolved with Web-based encyclopaedias such as the Stanford Encyclopedia of Philosophy and Internet Encyclopedia of Philosophy which are more easily updated (Elvebakk, 2008, The encyclopedias, paras 1-3). The additional advantages of 'dynamic' Web-based encyclopaedias include the ability to include information without size or volume restrictions, reducing the time delay between article completion and publication, removing the expense of printing or loading to disks, and being more responsive to changes in new technology (Hammer \& Zalta, 1997, pp. 48-49). Furthermore, Pack (2004, pp. 30, , para. 1) describes the Internet Encyclopedia of Philosophy as containing original articles as well as adapted work, which contrasts with Kister's (1994, p. 4) earlier statement "almost all encyclopaedias are tertiary compilations based on secondary sources". 


\subsection{Collaborative Encyclopaedias}

Collaborative encyclopaedias are so called for the reason that their articles are not written by one author but many; anyone with 'knowledge' or 'expertise' is able to collaborate with other interested parties in writing an article on a subject or topic. In the example of Wikipedia (2009), authors originally were able to contribute anonymously; articles are monitored by an unnamed group of volunteer 'editors'. More recently, Wikipedia has modified its policy of anonymity to new contributors in an attempt to minimise deliberate misinformation ("Wikipedia tightens editing policy," 2009).

Citizendium ("Citizens' compendium," 2009) is another collaborative encyclopaedia, but one that requires authors and editors register their names and credentials to increase the accuracy and reliability of articles. Open-Site (Open-Site Foundation, 2009) is also a collaborative encyclopaedia whose articles are edited by volunteers. Other characteristics of these encyclopaedias are they are all freely accessible via the Internet, and their content is able to be used under Creative Commons (CC Aotearoa New Zealand, n.d.) or GNU Free Documentation Licence ("GNU operating system," 2009) guidelines. An example of a subject specific collaborative encyclopaedia is the Encyclopaedia of Philosophy of Education (2010) which welcomes alternative views and articles to be submitted for peer review before publishing on their website.

Current literature on collaborative encyclopaedias centres on their use and role in academic research. Studies assessing Wikipedia's articles (in historical articles, scientific citations and popular information) for comprehensiveness, reliability, quality and accuracy (Nielsen, 2007; Rector, 2008; Royal \& Kapila, 2009) have found accuracy, quality and bias to be areas of concern (Rector, 2008; Royal \& Kapila, 2009) but scientific citations to be generally reliable 
(Nielson, 2007, abstract). Gorman (2007), Svoboda (2006), Santana and Woods (2009), and Waters (2007) discuss the unsuitability of using Wikipedia in academic research, citing lack of accuracy (Waters, 2007), “contributing to information entropy” (Gorman, 2007, p. 275), and lack of transparency in editorial control and author management (Santana \& Woods, 2009b).

Lim's (2009) web survey of undergraduate students at a United States university investigated how and why they use Wikipedia, their opinion of its information quality, and students' confidence in evaluating Wikipedia's information quality (p. 2189). Results were to some extent contradictory with approximately a third of respondents indicating Wikipedia was used for academic purposes, but did not use it for "finding articles or references or for conducting research" (Lim, 2009, p. 2195). A section of Schwietzer's (2008) study of Wikipedia included examining its use by undergraduate psychology students at Arizona State University. Analysis of questionnaires completed by first and senior year undergraduates showed $0.6 \%$ and $4.5 \%$ respectively cited Wikipedia in a paper or project (Schweitzer, 2008, pp. 83-84). Thus these studies indicate a collaborative encyclopaedia was used and cited at undergraduate university level, but their results cannot be interpreted to suggest collaborative encyclopaedias will be cited to any extent in higher degrees.

\subsection{Citation Studies of Theses and Dissertations}

In the area of collection management, previous studies (Edwards, 1999; Haycock, 2004; Kuyper-Rushing, Mar 1999; Pancheshnikov, 2007; Waugh \& Ruppel, 2004; Yeap \& Kiran, 2008) have examined citations from students' theses and dissertations and compared the cited publications to their availability in library collections; almost all using student papers from a single department or subject at a specific university. Kuyper-Rushing (1999) chose to 
study dissertations from music doctoral programs across the United States to investigate the core journals cited. Kushkowski, Parsons, and Wiese's (2003) longer study analysed citation characteristics and trends found in master's and doctoral papers written between 1973 and 1992 from lowa State University. Biele, Boote and Killingsworth (2004) believe that studies using data from a single institution do not produce results which could be generalized to other learning institutions or libraries; their study of education dissertations were selected from three US institutions (p. 348).

However, the predominant focus of these studies has been on serials such as journals, books and monographs with any resulting data on encyclopaedia citations only a by-product of these studies. These studies have either revealed a very low rate of citations of encyclopaedias, for example, 1.14\%, (Yeap \& Kiran, 2008, p. 33), or contained little or no detail on material types to show if encyclopaedia citations were counted (Biele, Boote and Killingsworth, 2004; Edwards, 1999; Haycock, 2004; Kushkowski, Parsons, \& Wiese, 2003; Kuyper-Rushing, 1999; Pancheshnikov, 2007; Waugh \& Ruppel, 2004).

The limitations of using citation analysis are widely known according to MacRoberts and MacRoberts (1989) who point out in addition to the variety of influences upon citation behaviour (as outlined above in the normative, social constructivist and multi-dimensional theories), the number of citations in a paper's bibliography may not equal the influences in the paper's content which should be referenced (p. 343). Their study of 15 genetics history papers "found that 719 references were needed to cover the information in the papers but there were only 216 references made, a coverage of only $30 \%$...the most thorough scholar cited only 64\% of his influences" (MacRoberts \& MacRoberts, 1989, p. 343). In addition to the 'informal influences' or 'tacit knowledge' (p. 344) not cited may also include background 
knowledge, where encyclopaedias may have been consulted for preliminary reading before proceeding to specific research on the topic required. The background reading may become internalized to the extent it is believed the knowledge was already present and therefore the original source is not referenced. MacRoberts and MacRoberts $(1989$, p. 345) proceed to suggest discussing citation motivations of papers with their authors would be ideal but time-consuming. Three studies (Brooks, 1985, 1986; Prabha, 1983) have conducted such surveys of authors.

\section{THEORETICAL FRAMEWORK}

Encyclopaedias can be defined as "a reference source published in either print or electronic form, summarizing basic facts and concepts on important subjects, or in a specialized encyclopedia, a particular subject, to provide a framework for initial understanding or springboard for further investigation" (Kister, 1994, pp. 3, 4). Based on this definition, the possible reasons why encyclopaedias would be used in academic research are to obtain background knowledge, to clarify concepts and definitions, to obtain an initial idea of the scope of a topic or subject before beginning specific research, and to consult the bibliography or recommended reading list following an article (Cassell \& Hiremath, 2006a, p. 72). This project seeks to measure the extent to which encyclopaedias (traditional and collaborative) are cited in New Zealand PhD dissertations as a prelude to future research into the reasons for citing encyclopaedias.

In measuring the extent to which collaborative encyclopaedias are cited in New Zealand PhD dissertations, this study seeks evidence of the use of collaborative encyclopaedias in New Zealand academic research and to examine the possible reasons (for example currency of information, unavailability of other sources) for their use given the concerns about their 
reliability, accuracy, and bias. The titles of collaborative encyclopaedias used, relevant disciplines, and dissertation topics will be described.

In addition to describing the patterns of encyclopaedia citations found, and exploring if these fit the bibliometric 'laws' (Hertzel, 2003; Merton, 1968) described in the 'Approaches to citation behaviour' section above, this study will also look at the reasons for citing encyclopaedias within the framework of the theories of citation behaviour. The normative (Garfield, 1996), social constructivist (Gilbert, 1977; Kaplan, 1965; Thorne, 1977; Van Raan, 1998, and multidimensional (Baldi, 1998b; Cozzens, 1989; Van der Veer Martens \& Goodrum, 2006) theories propose possible reasons for motivating citation behaviour ranging from citing background reading, reward and persuasion, to accessibility of publications; this study's analysis will consider which theory best describes the reasons for citing encyclopaedias.

This study is intended as a preliminary quantitative analysis of encyclopaedia citations in New Zealand PhD dissertations; it is hoped that this study will stimulate future in-depth investigation in this field.

\section{METHODOLOGY}

\subsection{Project Description}

This project is a quantitative study examining a sample of New Zealand PhD dissertations for encyclopaedia citations, and a comparative analysis of the citations by quantity, title, format and discipline. This data may be used to point towards the characteristics of encyclopaedias used in academic research and contribute towards librarians training users in information literacy to find a wider range of sources for research. 


\subsection{Project Objectives}

- To establish if encyclopaedia collections in university libraries are used as resources by $\mathrm{PhD}$ researchers

- To determine the level of use of online and print-based encyclopaedias by $\mathrm{PhD}$ researchers

\subsection{Research Questions}

1. To what extent are encyclopaedias cited in the sample of PhD dissertations in 2007 - 2008, compared to other types of citation sources (for example, monographs, journals, conference proceedings)?

2. To what extent do the proportions of encyclopaedia citations in the sample in 2007 -2008 vary by academic discipline?

3. To what extent is the proportion of encyclopaedia citations to discipline-specific or general encyclopaedias? What are the titles of encyclopaedias cited? Are they in printed or electronic format?

4. To what extent is the proportion of citations to 'traditional' encyclopaedias and collaborative encyclopaedias?

5. What are the characteristics of the two most cited encyclopaedias, the features of their citations, and the topics of the dissertations which have cited them?

\subsection{Definitions}

\subsubsection{Specification and definition of variables:}

- $\quad$ Citations: listing by author(s), title, publication title, date/place of publication (for books) to acknowledge sources of information or quotes referenced in the article or paper ("Citation," n.d.; Moed, 2005, p. 11) 
- PhD dissertation: a written essay, based on research, prepared by a candidate to meet the full or partial requirements of a Doctor of Philosophy degree ("Dissertation," 2008, p. 415)

- disciplines: subject fields of academic study, requiring specific teaching and research within higher education ("Disciplines," 2009)

- $\quad$ encyclopaedias: "a reference source published in either print or electronic form, summarizing basic facts and concepts on important subjects, or in a specialized encyclopaedia, a particular subject, to provide a framework for initial understanding or springboard for further investigation" (Kister, 1994, pp. 3, 4).

- traditional encyclopaedias: contain articles signed or initialled by their author who is typically a qualified expert in the field, the articles and publication is managed by recognized and qualified editorial management

- collaborative encyclopaedias: articles can be co-written by many authors, often anonymously; anyone with 'knowledge', or 'expertise' is able to collaborate with other interested parties in writing an article on a subject or topic. Article editing may also be done anonymously by volunteers

\subsubsection{Interrelationships:}

- $\quad$ the dependent variable to be measured are the citations from each dissertation

- independent variables: factors which relate to and have a causal influence on citations in this project are the encyclopaedias, specifically title, date, general or specific by subject; print or electronic format, traditional or collaborative); dissertations; the disciplines in which each dissertation is written 


\subsection{Population}

Within universities, research is carried out at varying levels: undergraduate assignments, postgraduate papers and reports, Honours papers, Masters theses, Doctoral dissertations and academic staff in faculties.

In New Zealand, there are currently eight universities, many of whom, in addition to offering study in the commerce, fine arts, science, and social science disciplines, make available study in specialised subjects such as medicine, dentistry, agriculture, veterinary science, and biomedicine.

\subsection{Sample}

To fit the cross-disciplinary requirements of the study, the sample population selected for research was a single university which had all its graduate research available online. PhD doctoral dissertations were selected for analysis in this study as being advanced research, they are available online for viewing, research and use (subject to copyright), are required to have lengthy and detailed bibliographies, were in a wide range of subjects, and were in suitable numbers to enable a survey to be made.

A convenience sample of all PhDs completed in 2007 and 2008 was selected from the University of Auckland's online research database, ResearchSpace@Auckland (University of Auckland, 2009), a total of 147 (73 in 2007, 74 in 2008).

\subsection{Delimitations}

A convenience sample of $\mathrm{PhD}$ dissertations available online was chosen to due to the time constraints of this project. Masters theses, honours and postgraduate research reports and 
papers were excluded as not all document types were available online; this presents opportunities for further research in this area in the future.

The period of study, 2007 and 2008, was selected to increase the possibility of citations of on-line accessible and collaborative encyclopaedias (being a relatively recent trend) and to ensure all PhDs completed in these years had been downloaded into university research databases.

To meet the criteria of a cross-disciplinary sample and the highest numbers possible over the specified period, PhD dissertations were selected from the University of Auckland. The PhD Theses collection in University of Auckland's online research database, ResearchSpace@Auckland (University of Auckland, 2009) included a number of MD dissertations (Doctorate of Medicine), and PhD dissertations which were only available in printed form or had access restrictions. The MD dissertations were excluded; the time restrictions of this project and University of Auckland Library staff unavailability resulted in the print and embargoed dissertations being unavailable for inclusion in this study. Two dissertations in the Chemistry discipline were unable to be examined in the timeframe as they contained multiple chapter reference lists with many duplicate entries and did not list the journal article titles cited. These delimitations reduced the final numbers of bibliographies which could be studied, with the effect being some bias could result through disciplines being under-represented. The following table list the numbers and disciplines of dissertations not examined:

\begin{tabular}{lcc}
\hline \multicolumn{1}{c}{ Discipline } & $\begin{array}{c}2007 \\
(n)\end{array}$ & $\begin{array}{c}2008 \\
(n)\end{array}$ \\
\hline Accounting & & 1 \\
Anatomy with Radiology & 1 & \\
Biological Science & 3 & 3 \\
Chemistry & & 2 \\
\hline
\end{tabular}




\begin{tabular}{|c|c|c|}
\hline Computer Science & & 1 \\
\hline Education & 1 & \\
\hline $\begin{array}{l}\text { Engineering (Chemical \& } \\
\text { Material) }\end{array}$ & & 1 \\
\hline Engineering (Civil) & & 1 \\
\hline English & & 1 \\
\hline $\begin{array}{l}\text { Film, Television \& Media } \\
\text { Studies }\end{array}$ & & 1 \\
\hline Health Psychology & 2 & \\
\hline History & & 2 \\
\hline Law & 1 & 1 \\
\hline $\begin{array}{l}\text { Management \& Employment } \\
\text { Relations }\end{array}$ & 1 & \\
\hline Maori Studies & 1 & \\
\hline Marketing & 1 & \\
\hline Medicine (MD) & 4 & \\
\hline $\begin{array}{l}\text { Molecular Medicine \& } \\
\text { Pathology }\end{array}$ & & 1 \\
\hline Optometry & 2 & \\
\hline Physiology & 1 & \\
\hline Sociology & & 1 \\
\hline Totals & 18 & 16 \\
\hline
\end{tabular}

Table 1: Excluded 2007 \& 2008 Dissertations by Discipline

\subsection{Limitations}

The limitations of citation analysis include the possibility that only the citations present may be studied, that is, if the full text of the paper was examined, more (or less) citations, such as those on background material, could be required to reference the paper's content, but were not provided by the author (MacRoberts \& MacRoberts, 1989, p. 373). Another disadvantage to studying the motivations for citation behaviour without surveying the authors concerned, results in more speculative and general reasons than from qualitative surveys of authors as has been undertaken by Brooks $(1985,1986)$ and Prabha $(1983)$. 
Biele, et al. (2004 p. 347-348) also question the validity of using dissertation citation analysis for evaluating research collections due to failure to assess their quality and appropriateness, and query with Haycock (2004) whether all PhD students have the necessary high level of information literacy to find the best sources of research for their dissertations (Haycock, 2004, p. 106). Part of Biele, et. al's (2004, p. 349) study assessed citations on criteria of scholarliness, currency and appropriateness. Further, they agree with Kuyper-Rushing (1999) that studies on one subject confined to a single institution can produce distorted results (Kuyper-Rushing, Mar 1999, pp. 153-163).

Another limitation of using citation analysis as a collection management assessment tool is the recommendation that it should be used in conjunction with other methods such as user studies, circulation statistics, and interlibrary loans to assess collections (Biele, Boote, \& Killingsworth, 2004; Edwards, 1999; Kushkowski, Parsons, \& Wiese, 2003; Kuyper-Rushing, Mar 1999).

Lower levels of academic research such as Master's theses and postgraduate research papers and reports may reveal higher levels of encyclopaedia citations, whereas this study will use PhD dissertations as its target population.

It was proposed to use analytical statistics to examine the bibliographies if there was sufficient data, however this proved not to be the case and descriptive statistics have been utilised to examine the findings.

Although this study may not be able to overcome all the limitations as outlined above, it is intended to provide some evidence on the types and frequency of citations to encyclopaedias to judge if concerns regarding the citation of collaborative encyclopaedias are warranted, and contribute additional data to assist in a review of academic library 
resources such as that recently conducted by the Victoria University of Wellington Library (Victoria University of Wellington, 2009).

\subsection{Procedures}

The selected dissertations were retrieved from the research database and the full text of papers downloaded. The title page (although the research is anonymous), reference list or bibliography of each dissertation was printed and assigned an identifying number before beginning analysis.

The following data from each bibliography was entered into an MS Excel spreadsheet: dissertation subject or discipline; citation numbers of each publication type, such as encyclopaedia, journal, newspaper/periodical, monograph, website; encyclopaedia citations, categorize further by: title, print or online format, and in collaborative or traditional form.

The project coding sheet is attached as Appendix A, with the source categories defined as (based on Knight-Davis \& Sung, 2008, p. 452):

- the categories of journal, book/monograph, government documents, newspapers/periodicals, theses/dissertations, conference papers/proceedings include their electronic or digital surrogates and 'in press' and unpublished material from the same source or of the same type

- the website/page category includes web documents which are not included in the above category

- the audio/visual category included podcasts and commercial television or radio recordings 
- primary sources include personal interview transcripts and recordings, field reports, surveys, personal communication, emails, and archive records

- the dictionary, biography, thesauri and bibliography category contained references to these sources

- the encyclopaedia columns measures any encyclopaedia cited; their titles are noted in a separate column, as is the format in which they were accessed; print or on-line

- the 'other' category includes any remaining sources unable to be classified in the above categories, or which had insufficient information in the citation

- 'discipline' indicates the faculty or department origins of the dissertation

\section{RESULTS \& DISCUSSION}

Table 2 (below) shows the numbers and percentage of citations by source in 2007 and 2008 PhD dissertations and relates to Research question 1, that encyclopaedias in $2007 \mathrm{PhD}$ dissertation bibliographies number 23 out of 22,760 citations, or $0.1 \%$ of the total. Of 2008 PhD dissertation bibliographies, encyclopaedia citations number 61 from a total of 20,308 citations, or $0.3 \%$. In contrast, journals and monographs constitute the largest proportion of sources of citations, making up 11,881 (52.2\%) for journals and 8,021 (35.2\%) for monographs in 2007, and 10,980 (54.1\%) journals and 6,264 (30.8\%) monographs in 2008. Thus Table 2 illustrates encyclopaedias comprise the smallest proportion of sources of citations in 2007 and is second only to Audio/Visual sources ( $n=50$, or $0.2 \%$ ) in 2008. 


\begin{tabular}{lllll}
\hline Citation Sources & 2007 & \multicolumn{3}{l}{2008} \\
\hline & $n$ & $\%$ & $n$ & $\%$ \\
\hline Journals & 11881 & $52.2 \%$ & 10980 & $54.1 \%$ \\
\hline Monographs/Books & 8021 & $35.2 \%$ & 6264 & $30.8 \%$ \\
\hline Conference Papers \&Proceedings & 1027 & $4.5 \%$ & 903 & $4.4 \%$ \\
\hline Government Documents & 577 & $2.5 \%$ & 330 & $1.6 \%$ \\
\hline Theses/Dissertations & 306 & $1.2 \%$ & 240 & $1.2 \%$ \\
\hline Primary Sources & 279 & $1.2 \%$ & 684 & $3.4 \%$ \\
\hline Newspapers/Periodicals & 270 & $1.2 \%$ & 244 & $1.2 \%$ \\
\hline Other & 187 & $0.8 \%$ & 379 & $1.9 \%$ \\
\hline Websites & 93 & $0.4 \%$ & 95 & $0.5 \%$ \\
\hline Dictionaries/Biographies/Thesauri & 52 & $0.2 \%$ & 78 & $0.4 \%$ \\
\hline Audio/Visual Sources & 44 & $0.2 \%$ & 50 & $0.2 \%$ \\
\hline Encyclopedias & 23 & $0.1 \%$ & 62 & $0.3 \%$ \\
\hline Totals & 22760 & $100 \%$ & 20309 & $100.0 \%$ \\
\hline
\end{tabular}

Table 2: Citations by Material Source in 2007 \& 2008 PhD Dissertations

Table 3 details the numbers of encyclopaedia citations found in each academic subject or discipline, and provides the information required in Research question 2 - the numbers of encyclopaedia citations by discipline in 2007 and 2008. The citations are distributed over varying disciplines, with the highest number in English; seventeen citations to encyclopaedias were counted in one English dissertation. The discipline of Biological Sciences recorded the third highest number $(n=11)$ of encyclopaedia citations in 2008 , this was largely due to two bibliographies listing seven and three citations respectively, plus one bibliography with one citation. A Statistics dissertation bibliography listed 12 encyclopaedia citations in 2008, contributing to an overall figure of 13 in the Statistics discipline.

\begin{tabular}{lcc}
\hline Discipline & 2007 & 2008 \\
\hline Anthropology & 1 & \\
Applied Language & 1 & \\
$\quad$ Studies \& Linguistics & & 11 \\
Biological Sciences & & 2 \\
Computer Science & & \\
Development Studies & 1 & \\
Education & 1 & \\
\hline
\end{tabular}




\begin{tabular}{|c|c|c|}
\hline $\begin{array}{l}\text { Engineering (Electrical \& } \\
\text { Electronic) }\end{array}$ & & 1 \\
\hline Engineering (Software) & 6 & \\
\hline Engineering (Mechanical) & & 2 \\
\hline English & & 17 \\
\hline French & & 3 \\
\hline Geography & 1 & \\
\hline History & & 3 \\
\hline $\begin{array}{l}\text { Information Systems \& } \\
\text { Operations Mgmt }\end{array}$ & 1 & \\
\hline Linguistics & 6 & \\
\hline Nursing & 1 & \\
\hline Political Science & 1 & 2 \\
\hline $\begin{array}{l}\text { Psychiatry \& Behavioral } \\
\text { Sciences }\end{array}$ & & 1 \\
\hline Psychology & 2 & \\
\hline Sociology/Women's Studies & & 2 \\
\hline Statistics & & 13 \\
\hline Theology & 1 & 5 \\
\hline Citation Totals & 23 & 62 \\
\hline
\end{tabular}

Table 3: Encyclopaedia Citations by Discipline

By overall disciplinary groups, figure 1 illustrates that the highest number of encyclopaedia citations are made by the Arts and Science faculties in 2008, with 27 and 26 citations respectively.

\begin{tabular}{lrr}
\hline Encyclopedia Citations by Faculty & & \\
\hline & 2007 & 2008 \\
Arts & 10 & 27 \\
Engineering & 6 & 3 \\
Science & 3 & 26 \\
Education & 1 & 0 \\
Medical \& Health Sciences & 1 & 1 \\
Theology & 1 & 5 \\
Business & 1 & 0 \\
\hline \multicolumn{1}{c}{ Citation Totals } & 23 & 62 \\
\hline
\end{tabular}

Table 4: Encyclopaedia Citations by Faculty 


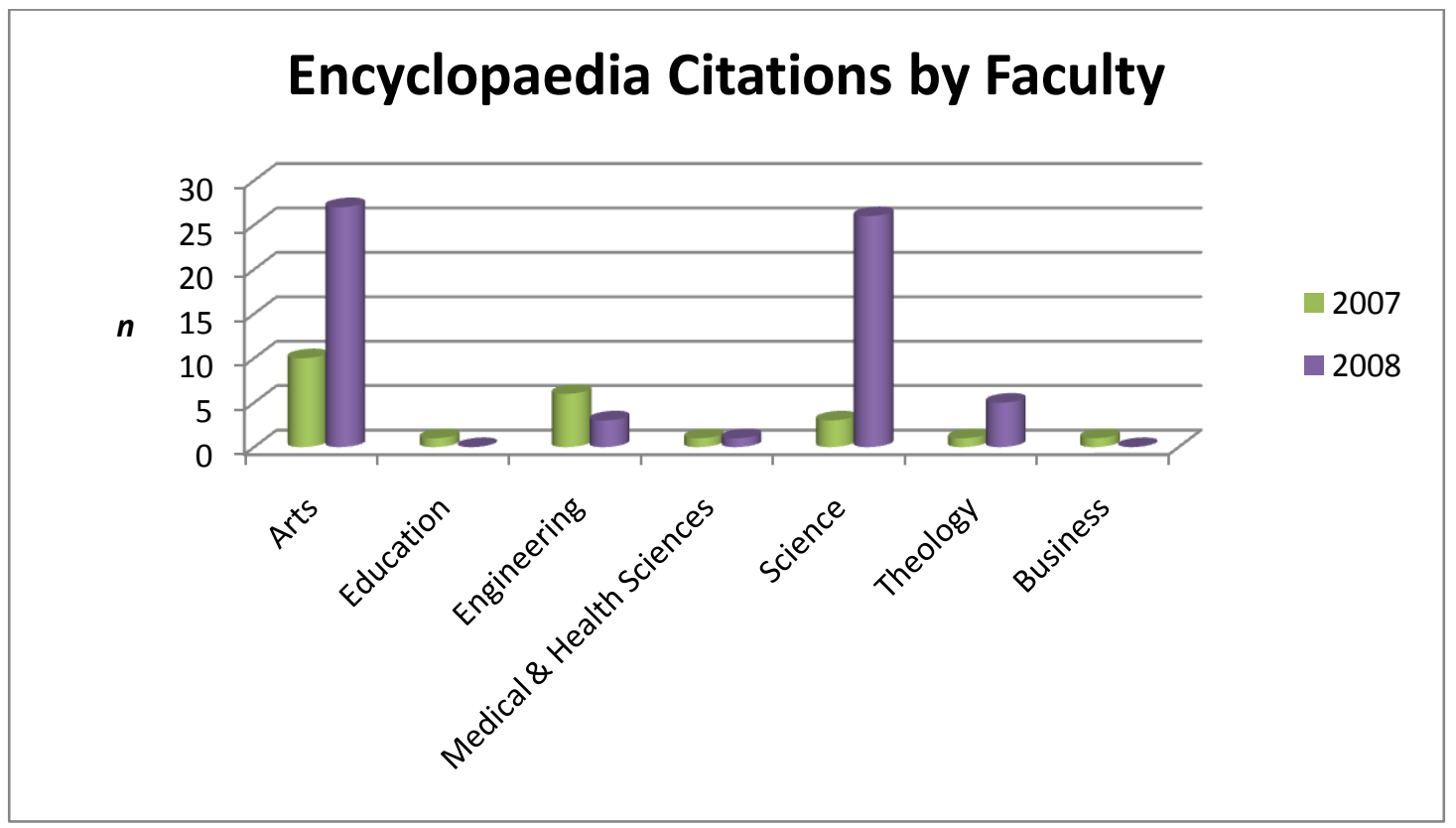

Figure 1: Encyclopaedia Citations by Faculty

Referring to Research question 3, Tables 5 and 6 show the proportion of encyclopaedia citations to general encyclopaedias and discipline-specific (or specialised) and their format. The majority of encyclopaedias $(n=19)$ referenced were specific to the discipline studied and were accessed in printed format; only eight general encyclopaedias were used. The Encyclopaedia of New Zealand is also available in online form as part of the Te Ara Encyclopaedia of New Zealand; three citations were sourced online and three other references to the Encyclopaedia of New Zealand were to its printed version. Six encyclopaedias were used in online format, of which only one was discipline-specific, the Encyclopaedia of Philosophy of Education. The general Encyclopaedia Britannica, available in both printed and online versions, received one citation each to the two versions. The highest number ( $n=32$ ) of citations to any one encyclopaedia is Wikipedia, followed by the Encyclopaedia of Marine Mammals ( $n=10)$. 


\begin{tabular}{lccc}
\hline Title & $\begin{array}{c}\text { Citations } \\
(n)\end{array}$ & Print & Online \\
\hline Wikipedia & 32 & & $*$ \\
Encyclopaedia of NZ & 6 & $*$ & $*$ \\
Te Ara Encyclopaedia of NZ & 5 & & $*$ \\
Encyclopedia of Britannica & 2 & $*$ & $*$ \\
Cyclopaedia of NZ & 1 & $*$ & \\
Encarta Online Encyclopedia & 1 & & $*$ \\
Encyclopedia Americana & 1 & $*$ & \\
Modern Encyclopaedia of Australia & 1 & $*$ & \\
and NZ & & & $\mathbf{5}$ \\
\hline Totals & $\mathbf{4 9}$ & $\mathbf{5}$ & \\
\hline
\end{tabular}

Table 5: General encyclopaedias by title, citations and format

\begin{tabular}{|c|c|c|c|}
\hline Title & $\begin{array}{l}\text { Citations } \\
\text { (n) }\end{array}$ & Print & Online \\
\hline Encyclopedia of Marine Mammals & 10 & $*$ & \\
\hline $\begin{array}{l}\text { Encyclopedia of Language \& } \\
\text { Linguistics }\end{array}$ & 6 & $*$ & \\
\hline $\begin{array}{l}\text { Companion Encyclopedia of History of } \\
\text { Medicine }\end{array}$ & 2 & $*$ & \\
\hline Encyclopedia of Early Christianity & 2 & $*$ & \\
\hline $\begin{array}{l}\text { Encyclopaedia of Language \& } \\
\text { Education }\end{array}$ & 2 & $*$ & \\
\hline Collectors' Encyclopedia of Shells & 1 & $*$ & \\
\hline Encyclopedia of Creativity & 1 & $*$ & \\
\hline Encyclopedia of Life Sciences & 1 & $*$ & \\
\hline Encyclopedia of Literature & 1 & $*$ & \\
\hline $\begin{array}{l}\text { Encyclopaedia of Missions. Descriptive, } \\
\text { historical, biographical, statistical, } \\
\text { with a full assortment of maps, a } \\
\text { complete bibliography, and lists of } \\
\text { Bible versions }\end{array}$ & 1 & $*$ & \\
\hline $\begin{array}{l}\text { Encyclopedia of Networking \& } \\
\text { Telecommunications }\end{array}$ & 1 & $*$ & \\
\hline $\begin{array}{l}\text { Encyclopedia of Nutritional } \\
\text { Supplements }\end{array}$ & 1 & $*$ & \\
\hline $\begin{array}{l}\text { Encyclopedia of Philosophy of } \\
\text { Education }\end{array}$ & 1 & & * \\
\hline $\begin{array}{l}\text { Encyclopedia of Post-Colonial } \\
\text { Literatures in English }\end{array}$ & 1 & $*$ & \\
\hline Encyclopedia of Psychological & 1 & $*$ & \\
\hline
\end{tabular}




\begin{tabular}{lccc}
\hline Assessment & & & \\
$\quad$ Encyclopedia of Software & 1 & $*$ & \\
$\quad$ Engineering & & & \\
Encyclopedia of World Literature & 1 & $*$ & \\
$\quad \begin{array}{l}\text { Illustrated Encyclopedia of Maori } \\
\text { Myths \& Legends }\end{array}$ & 1 & $*$ & 1 \\
Social Science Encyclopedia & 1 & $*$ & 18 \\
\hline Totals & 36 & 18 \\
\hline
\end{tabular}

Table 6: Subject specific encyclopaedias by title, citations, and format

In relation to Research question 4, only Wikipedia and the Encyclopaedia of Philosophy of Education ( $n=33,39 \%)$ are collaborative with the characteristic that any interested party may contribute. However, unlike Wikipedia, the Encyclopaedia of Philosophy of Education states that entries will be peer-reviewed ("Adding your entry," 2010), all articles and entries are accompanied by the author's name, and the editorial board lists the names of current and founding editors. Also unlike Wikipedia, although the Encyclopaedia of Philosophy of Education is an Internet-based encyclopaedia, it provides access to archived older versions of its pages ("Old revisions," 2010). The remaining encyclopaedia titles ( $n=52,61 \%)$ are traditional, characterised by the publishing of the names of editors and authors, and an obvious trait of printed encyclopaedias, the articles and information contained within, once published, cannot be changed without printing a new volume or version. The printed versions of the Encyclopedia of Life Sciences (Wiley-Blackwell, 1999), Encyclopedia of Missions (Making of America, 2005), Encyclopedia of Networking and Telecommunications (Sheldon, 2001) and the Encyclopedia of New Zealand (Te Ara, 1966) are also available online but are not able to be altered or updated unlike true Internet-based encyclopaedias. Table 7 and Figure 2 (below) depicts the proportions of collaborative and traditional encyclopaedias cited: 


\begin{tabular}{|c|c|c|}
\hline & Collaborative & Traditional \\
\hline Wikipedia & 32 & \\
\hline Philosophy of Education & 1 & \\
\hline Encyclopedia of Marine Mammals & & 10 \\
\hline Encyclopaedia of NZ & & 6 \\
\hline Encyclopedia of Language \& Linguistics & & 6 \\
\hline Te Ara Encyclopedia of NZ & & 5 \\
\hline Encyclopedia Britannica & & 2 \\
\hline Encyclopedia of Early Christianity & & 2 \\
\hline Encyclopedia of History of Medicine & & 2 \\
\hline Encyclopedia of Language \& Education & & 2 \\
\hline Collectors Encyclopaedia of Shells & & 1 \\
\hline Cyclopaedia of NZ & & 1 \\
\hline Encarta Online Encyclopedia & & 1 \\
\hline Encyclopedia Americana & & 1 \\
\hline Encyclopedia of Creativity & & 1 \\
\hline Encyclopedia of Life Sciences & & 1 \\
\hline Encyclopedia of Literature & & 1 \\
\hline Encyclopedia of Missions & & 1 \\
\hline Encyclopedia of Networking \& Telecommunications & & 1 \\
\hline Encyclopedia of Nutritional Supplements & & 1 \\
\hline Encyclopedia of Post-Colonial Literatures in English & & 1 \\
\hline Encyclopedia of Psychological Assessment & & 1 \\
\hline Encyclopedia of Software Engineering & & 1 \\
\hline Encyclopedia of World Literature & & 1 \\
\hline $\begin{array}{l}\text { Illustrated Encyclopedia of Maori } \\
\text { Myths \& Legends }\end{array}$ & & 1 \\
\hline Modern Encyclopedia of Australia \& NZ & & 1 \\
\hline Social Science Encyclopedia & & 1 \\
\hline Totals & 33 & 52 \\
\hline
\end{tabular}

Table 7: Citations to traditional and collaborative encyclopedias 


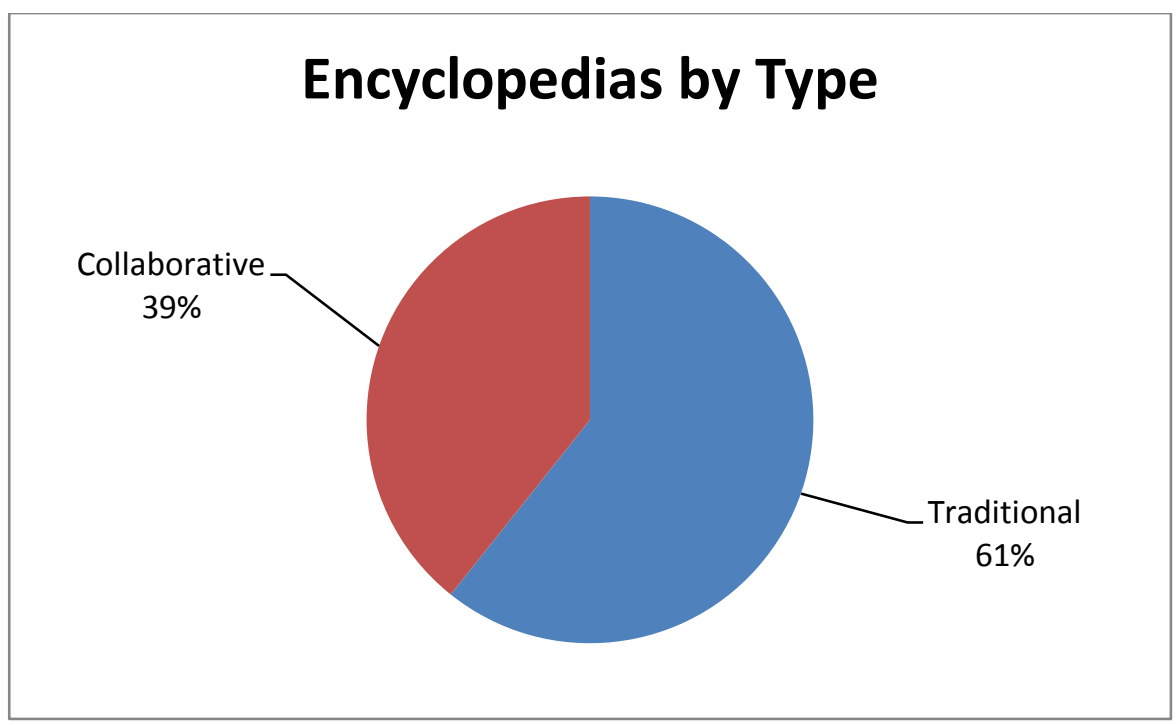

Figure 2: Encyclopaedias by Type

The characteristics of the two most cited encyclopaedias, the Encyclopedia of Marine Mammals and Wikipedia, are diverse: the former is a specialised encyclopaedia (cited ten times by two dissertations) in Biological Science, and available only in printed format. It is a traditional encyclopaedia containing entries by named authors who most probably are experts and well known to those familiar with the field of study. Wikipedia was cited 32 times by varied disciplines, and is a general, collaborative (and anonymously authored) encyclopaedia available only via the Internet. Table 8 provides an outline of their citations and the relevant topics or disciplines (with reference to Research question 5):

\begin{tabular}{|c|c|c|c|c|}
\hline & $\begin{array}{l}\text { Topic/ } \\
\text { Discipline }\end{array}$ & $\begin{array}{l}\text { Dissertation } \\
\text { Bibliographies } \\
\text { (n) }\end{array}$ & $\begin{array}{c}\text { Citations } \\
\text { (n) }\end{array}$ & Nature of Citation \\
\hline $\begin{array}{l}\text { Encyclopedia of } \\
\text { Marine Mammals }\end{array}$ & $\begin{array}{l}\text { Biological } \\
\text { Sciences - } \\
\text { Marine }\end{array}$ & 2 & 10 & $\begin{array}{l}\text { Original source of } \\
\text { information }\end{array}$ \\
\hline \multirow[t]{3}{*}{ Wikipedia } & $\begin{array}{l}\text { Computer } \\
\text { Science }\end{array}$ & 1 & 2 & $\begin{array}{l}\text { Define concept } \\
\text { Detail mathematical } \\
\text { function }\end{array}$ \\
\hline & $\begin{array}{l}\text { Engineering - } \\
\text { Software }\end{array}$ & 1 & 5 & $\begin{array}{l}\text { Define terms/ } \\
\text { concept }\end{array}$ \\
\hline & Engineering - & 1 & 2 & Define concept and \\
\hline
\end{tabular}




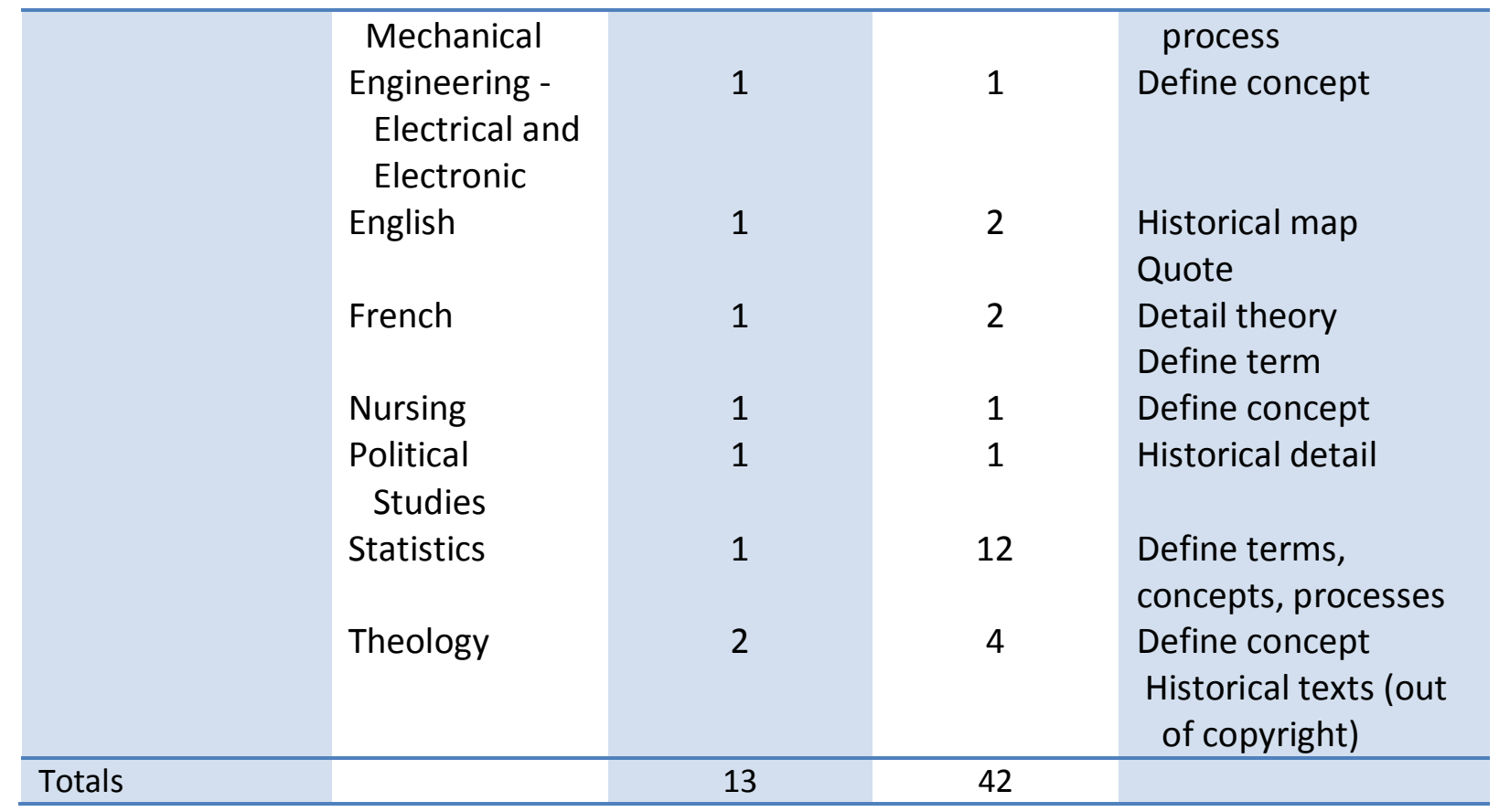

\section{Table 8: Characteristics of the two most cited encyclopaedias}

Table 8 shows by faculty, Science (made up of Computer Science and Statistics) listed the highest of 14 citations to Wikipedia, Engineering (Software, Mechanical and Electrical and Electronic) have 8 Wikipedia citations; Arts (English, French, Political Studies and Theology) received 9 citations; and the Medical and Health Sciences faculty (Nursing) contained one citation to Wikipedia (overall total $n=32$ ). The column listing the number of dissertation bibliographies illustrates the total $(n=13)$ authors involved as part of this section of analysis; thereby showing only 13 or $8.8 \%$ of a total of 147 dissertations examined are in this category. The total number of individual authors $(n=11)$ citing Wikipedia remains very small as a proportion of total dissertations, comprising $7.4 \%$ of 147 dissertations.

The table also lists the nature or probable reasons for the citations, which were obtained by examining the texts of the citations. This was more difficult with citations to the Encyclopedia of Marine Mammals which consisted of the entry's title, author and page numbers. The entry titles tended to be specific names of mammal species relating to the dissertation subject, leading to the conclusion that the citations were made to the 
encyclopaedia as the original source of information. Citations to Wikipedia were more specific as the concept, term, process or mathematical function was listed as the title, and the URL (Uniform Resource Locater) address was also listed. As Table 8 shows, citations to Wikipedia tended to be for clarification or defining terms, concepts and processes; there appeared to be only one quote, and three citations were for a historical map and details.

\section{SUMMARY \& CONCLUSIONS}

This study has examined the extent to which encyclopaedias are cited in a sample of New Zealand PhD dissertations. It has looked at characteristics of cited encyclopaedias, specifically if they are general or discipline-specific in type, traditional or collaborative in nature, and in printed or online format. An examination of the bibliographies of available 2007 and 2008 PhD dissertations from the University of Auckland has found citations to encyclopaedias make up a very small ( $n=23$, or $0.1 \%$ in $2007 ; n=62$, or $0.3 \%$ in 2008 ) proportion of total citations. Of the citations to encyclopaedias, the Arts and Science faculties each received the highest number of citations ( $n=27$ and 26 respectively), with the disciplines English ( $n=17)$ and Statistics $(n=13)$ receiving the most citations. The use of specialised $(n=19)$ outnumbered general $(n=8)$ encyclopaedias; and printed format encyclopaedias $(n=23)$ were used more often than in online $(n=6)$ format. Traditional style encyclopaedias were more frequently (61\%) used than collaborative (39\%) style encyclopaedias such as Wikipedia and the Encyclopaedia of Philosophy of Education. Wikipedia, a general, collaborative, and on-line format encyclopaedia, received the highest ( $n=32)$ number of citations, from 11 dissertations or bibliographies. 
As the results show, the very low rate of encyclopaedia citations indicates that the reasons for citing them cannot be attributed to direct relevance to the varied dissertation topics (compared to the very high rates of journal, monograph and conference papers/proceedings citations). The reasons are more likely to be due to citing original sources of background detail or history, and defining technical/scientific concepts (Garfield, 1996, pp. 451-452). This appears to be the case with citations to both specialised and general encyclopaedias; the Encyclopaedia of Modern Australia and New Zealand, Encyclopaedia Britannica, Te Ara Encyclopaedia of New Zealand, Encyclopaedia of New Zealand, and occasionally Wikipedia were cited for historical details referenced in dissertations in English, History, and Political Studies. The use of most encyclopaedias in print format is most likely because they are published in print form only, although as mentioned above, there are a few printed encyclopaedias such as the Encyclopedia of Life Sciences (Wiley-Blackwell, 1999), Encyclopedia of Missions (Making of America, 2005), Encyclopedia of Networking and Telecommunications (Sheldon, 2001) and the Encyclopedia of New Zealand (Te Ara, 1966) which are also available online. Citations to encyclopaedia in on-line format appear to have been made either because it was the only format available, for example in the cases of Encarta Online Encyclopedia (defunct as of 31 October 2009 (Physorg, March 30, 2009)), Wikipedia, Te Ara Encyclopedia of New Zealand (Culture and Heritage Ministry, 2010), and the Encyclopedia of Philosophy of Education (2010); or due to the accessibility of the format, as revealed by citations to the online versions of Encyclopaedia Britannica, and the Encyclopedia of New Zealand (Te Ara, 1966). That the results show traditional style encyclopaedias were mainly cited is perhaps unsurprising as Table 7 shows, there are more encyclopaedias where articles are written by (named) subject experts than collaborative encyclopaedias which are a relatively recent development requiring time to establish a 
reputation for 'credibility' and 'quality control' (Maron \& Smith, 2009, Summary of findings) before being accepted in academic research.

The relatively high use ( $n=32$; or $37.6 \%$ of encyclopaedia citations) of Wikipedia (as outlined in Table 8 above) could be attributed to reasons such as accessibility (for clarifying concepts, definitions), unavailability of other sources (Table 8 shows it has used for citing historical texts out of print and copyright) and possibly currency of information, given the higher usage in Science faculty dissertations. The collaborative style of Wikipedia may have an advantage over other resources in that changes or developments in technology can be quickly incorporated into its online pages by enthusiasts.

The proposed reasons for the citation of encyclopaedias as outlined above, citing original sources of background detail or history, and defining technical/scientific concepts (Garfield, 1996, pp. 451-452), pragmatism due to format, style and content availability, accessibility, and currency of information, is best defined by the 'multi-dimensional' (Camacho-Minano \& Nunez-Nickel, 2009, p. 755) theory of citation behaviour. The theory combines the normative (Garfield, 1996, pp. 451-452) and social constructivist (Gilbert, 1977; Kaplan, 1965; Thorne, 1977; Van Raan, 1998) theories of citation behaviour together with more specific and pragmatic reasons such as physical accessibility (Liu, 1997). The author anonymity characteristic of Wikipedia does not fit the social constructivist theory with its emphasis on 'social', 'reward' and 'persuasion' (Gilbert, 1977; Kaplan, 1965, pp. 115 - 117; p. 181) reasons as they are reliant on knowing the cited author's identity.

The bibliometric 'laws' of the Matthew effect (Merton, 1968, pp. 56-63), publication bias (Beck \& Manuel, 2008, p. 187), Lotka's Law (Hertzel, 2003, pp. 303 - 306), and Bradford's Law (Hertzel, 2003, pp. 306 - 311), as described above in 2.1 Approaches to citation analysis, 
cannot in reality be applied to the analysis of encyclopaedia citations in this study as the Matthew effect, which states well known authors are cited more often than less recognised authors in the same field regardless of source accessibility (Beck \& Manuel, 2008, p. 187) would attempt to identify this trend in a single discipline of study, and one of the parameters of this study is to examine encyclopaedia citations in any discipline. Furthermore, this study did not examine the detailed level of authors of articles, which would be required for an application of the Matthew effect. Similarly, Lotka's Law, which deems a small proportion of authors produce the bulk of publications in a field of study (Borgman \& Furner, 2002, p. 49) and are therefore cited more often, is more applicable to studying authors in a specific discipline, unlike this study, which is providing a initial assessment of the role of encyclopaedias in academic research in New Zealand by measuring their citations in all disciplines in a sample of PhD dissertations. Likewise, publication bias analysis of articles to determine if positive and significant research is more likely to be published (Beck \& Manuel, 2008, p. 187) would entail studying articles' texts, which is not an objective of this study but could be included as part of a study of encyclopaedias that contain primary research. Bradford's Law, which relates to a journal publishing trend that a small number of journals in a field of study tends to publish approximately a third of all articles, thereby influencing citation and library holdings decisions (Beck \& Manuel, 2008, p. 188), also is not applicable to achieving the objectives of this study, which is to discover if citations to encyclopaedias occur in any field of study and the format of the encyclopaedias used; Bradford's law would be useful in a study analysing the use of encyclopaedias in a specific field. 
This study has found that collaborative encyclopaedias, namely, the Encyclopaedia of Philosophy of Education and Wikipedia, are cited in PhD dissertations in New Zealand, although it constitutes a very small proportion of all citations, 7 of 22,760 citations in 2007 or $0.03 \%$; 26 of 20,309 citations in 2008 or $0.13 \%$ ). The total number of authors of these dissertations is 13 , or $8.8 \%$ of a total of 147 dissertations. The number of individual authors ( $n=11$ ) citing Wikipedia remains small as a proportion of the total, comprising $7.4 \%$ of 147 dissertations.

The Encyclopaedia of Philosophy of Education states it welcomes anyone to contribute articles and alternative views to its website, but has a peer review process ("Adding your entry," 2010) along with named editors who are well known in the study field, thereby removing the contentious issue of the anonymity of article authors and editors. In other traits then, the internet-based Encyclopaedia of Philosophy of Education is a traditionalstyle encyclopaedia compared to Wikipedia.

With the possible reasons (as discussed above) for citing Wikipedia being accessibility, unavailability of other sources, and information currency, the concerns (Gorman, 2007; Santana \& Woods, 2009a; Svoboda, 2006; Waters, 2007) regarding the difficulty of verifying the accuracy and reliability of information from Wikipedia appear to be reasonable, based on its 'wiki' style which permits new articles and changes to existing articles to be made with relative anonymity, and without authoritative references. Unavailability of other sources, such as for ancient theological texts, may mean that an unsuccessful search for other sources has been made, citing Wikipedia in this instance is therefore necessary, but the original source could still be referenced (if available), as recommended by Wikipedia itself ("Citing Wikipedia," 2010, para. 1). Accessibility could be interpreted as other sources 
for the information have been found, but the user-friendliness of Wikipedia influenced the choice of citation source. However, it could also mean the convenience of access to Wikipedia (and perhaps time constraints) were factors in the choice of reference source for (for example) definitions of concepts. Information currency is a valid reason for citing Wikipedia as discussed earlier, that contributors are able to quickly update changes in information to web pages, but although Nielson (2007, abstract) found scientific citations to Wikipedia to be generally reliable, it is assumed that PhD candidates are sufficiently experienced in their field of study to be able to verify information found in Wikipedia with other sources. This assumption is challenged by Biele et al. 's (2004) study that examined "appropriateness, or fit of the material type to the topic" (p. 351) as one of its criteria in examining dissertations and found "...the presumed quality of dissertation citations was not substantiated" (p. 352). Wikipedia itself warns that solely citing encyclopaedias is regarded unfavourably, that its "articles should be used for background information, as a reference for correct terminology and search terms, and as a starting point for further research" and to confirm its content with other sources ("Cite: Important note," 2010; Citing Wikipedia," 2010). As the majority of the citations to Wikipedia (27 of 32) as listed in Table 8 appear to be for defining concepts and terms, this could be seen as an appropriate usage of Wikipedia. However, with the widely known concerns expressed about the suitability of citing Wikipedia at any level of academic research, it is still surprising that this study found (albeit small) a measurable level of citations to Wikipedia in a sample of PhD dissertations in New Zealand.

The results of this study may be useful to university librarians and faculties in training students before they begin research for higher degrees. 


\subsection{Suggestions for future research:}

As stated earlier, this study is intended as a preliminary quantitative analysis of encyclopaedia citations in New Zealand PhD dissertations; it is hoped that this study will stimulate future in-depth investigation in this field. A number of suggestions for future research that have arisen during this study are: of those that have cited encyclopaedias, how many are of quotations, rather than just sources of ideas? Considering the reasons why the extent of encyclopaedia citations is particularly high in some disciplines or low in others is another proposal. For example, if the extent of citations is particularly low in some disciplines, the likely reasons may be due to the unavailability or inaccessibility of specialized encyclopaedias or lack of relevance to the topic. Conversely, if the encyclopaedia citation rate is relatively high in a discipline, this may be due to an encyclopaedia containing primary research articles which have been cited as background material, or high numbers of specialised encyclopaedias in technical disciplines such as engineering. Or, ultimately, the reason could be due to differing levels of information literacy between students from diverse disciplines of study.

As mentioned in the limitations section above, lower levels of academic research such as Master's theses and postgraduate research papers and reports may reveal higher levels of encyclopaedia citations, producing different results from this study.

A final suggestion is a qualitative study surveying authors who have cited encyclopaedias could provide interesting data on this topic about why (or not) encyclopaedia citations have been made. In particular, qualitative research as a follow-up on Lim's (2009) survey result that approximately a third of respondents used Wikipedia but not for "finding articles or references or for conducting research" (Lim, 2009, p. 2195) may shed some light on why 
people use Wikipedia, their reasons for choosing to cite it, and if verification of information is made. 


\section{APPENDIX A: Project Coding Sheet}

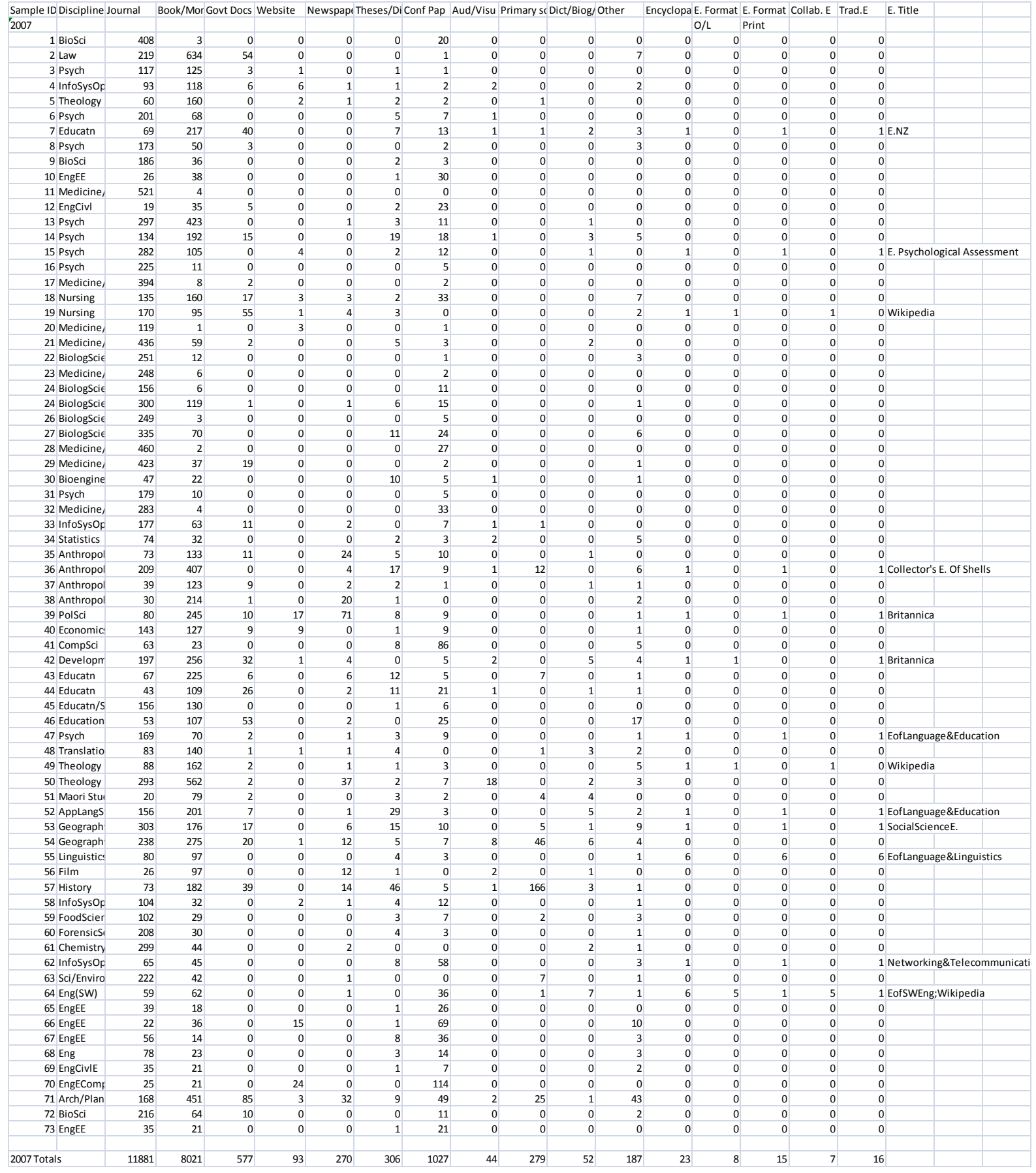


Sample ID Discipline Journal Book/Mor Govt Docs Website Newspape Theses/Di Conf Pap Aud/Visu Primary sc Dict/Biog/Other Encyclopa E. Format E. Format Collab. E Trad.E E. Title

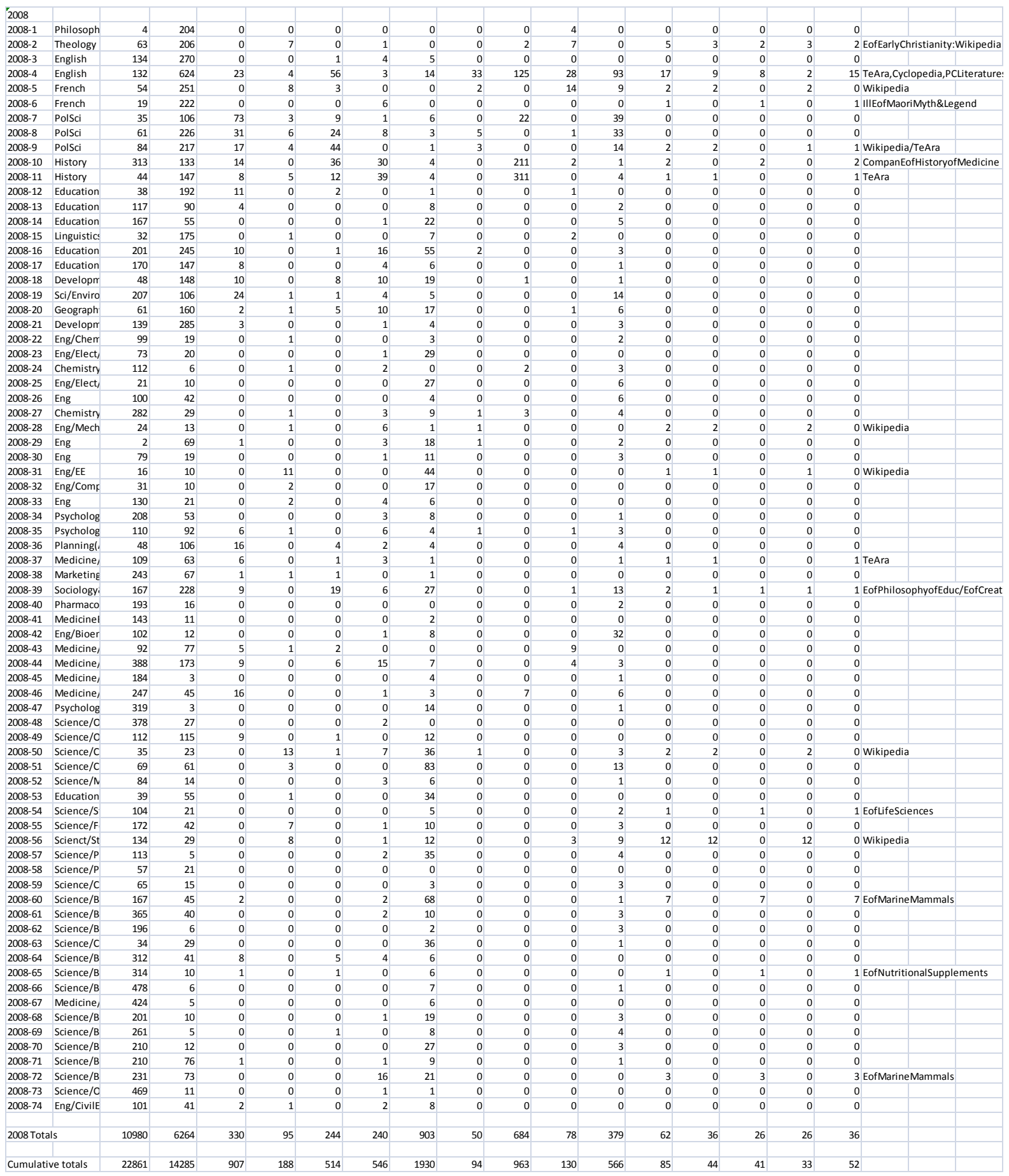




\section{REFERENCES \& BIBLIOGRAPHY}

\section{$8.1 \quad$ References}

Adding your entry. (2010). M. A. Peters, P. Ghiraldelli, B. Zarnic, A. Gibbons \& R. Heraud (Eds.), Encyclopaedia of philosophy of education Retrieved from http://www.vusst.hr/ENCYCLOPAEDIA/doku.php?id=information for current and $p$ erspective contributors

Baldi, S. (1998a). Normative versus social constructivist processes in the allocation of citations: A network-analytic model. American Sociological Review, 63(6), 829-846. Retrieved from http://www.jstor.org/stable/2657504

Baldi, S. (1998b). Normative versus social constructivist processes in the allocation of citations: A network-analytic model. American Sociological Review, 63(6), 829-846.

Beck, S. E., \& Manuel, K. (2008). Bibliometrics Practical research methods for librarians and information professionals (pp. 165-194). New York: Neal Schuman.

Biele, P. M., Boote, D. N., \& Killingsworth, E. K. (2004). A microscope or a mirror?: A question of study validity regarding the use of dissertation citation analysis for evaluating research collections. Journal of Academic Librarianship, 30(5), 347-353. Retrieved from Library Literature and Information Full Text database

Bonzi, S., \& Snyder, H. (1991). Motivations for citation: A comparison of self citation and citation to others Scientometrics, 21(2), 245-254. doi: 10.1007/BF02017571

Borgman, C., \& Furner, J. (2002). Scholarly communication and bibliometrics. Annual Review of Information Science and Technology, 36(1), 2-72. Retrieved from doi:10.1002/aris.1440360102

Brooks, T. A. (1985). Private acts and public objects: an investigation of citer motivations. Journal of the American Society for Information Science, 36(4), 223-229. Retrieved from $A B I / I N F O R M$ Global database

Brooks, T. A. (1986). Evidence of complex citer motivations. Journal of the American Society for Information Science, 37(1), 34-36. Retrieved from ABI/INFORM Global database

Camacho-Minano, M., \& Nunez-Nickel, M. (2009). The multilayered nature of reference selection. Journal of the American Society for Information Science and Technology, 60(4), 754-777. doi: 10.1002/asi.21018

Cassell, K. A., \& Hiremath, U. (2006a). Answering questions about anything and everything encyclopedias Reference and information services in the 21st century (pp. 69-92). London: Facet 
Cassell, K. A., \& Hiremath, U. (2006b). User instruction in the reference department Reference and information services in the 21st century: an introduction (pp. 273286). London: Facet.

CC Aotearoa New Zealand. (n.d.). Creative commons Aotearoa New Zealand Retrieved 13 January, 2010, from http://www.creativecommons.org.nz/

Citation. (n.d.). WordNet search, 2009(24 November). Retrieved from http://wordnetweb.princeton.edu/perl/webwn?s=citation

Cite: Important note. (2010). Wikipedia, the free encyclopedia. Retrieved from http://en.wikipedia.org/w/index.php?title=Cancer\&oldid=342296922

Citing Wikipedia. (2010). Wikipedia, the free encyclopedia, (8 February). Retrieved from http://en.wikipedia.org/wiki/Wikipedia:Citing Wikipedia

Citizens' compendium. (2009). Retrieved from http://en.citizendium.org/wiki/Creative Commons CC-by-sa 3.0

Computer ethics and intelligent technologies. (2008). M. Quigley (Ed.) Encyclopedia of Information Ethics and Security (pp. 83-88). Retrieved from Gale Virtual Reference Library database

Cozzens, S. E. (1989). What do citations count? The rhetoric-first model. Scientometrics, 15(5-6), 437-447. Retrieved from http://www.springerlink.com.helicon.vuw.ac.nz/content/g200488748040xm4/?p=da 186e06b5e149dcbb641a1bb44edbb1\&pi=7 doi:10.1007/BF02017064

Crothers, C. (2008). Encyclopaedias, handbooks, dictionaries, collections and companions: assessing collective works in sociology. International Sociology, 23(2), 171-179. doi: $10.1177 / 0268580907086372$

Culture and Heritage Ministry. (2010). Te Ara The encyclopedia of New Zealand Retrieved from http://www.teara.govt.nz/

Disciplines. (2009). S. Wallace (Ed.) A Dictionary of Education Retrieved from Oxford Reference Online database

Dissertation. (2008). C. Soanes \& A. Stevenson (Eds.), Concise Oxford english dictionary (pp. 415).

Edwards, S. (1999). Citation analysis as a collection development tool: a bibliometric study of Polymer science theses and dissertations. Serials Review, 25(1), 11-21. Retrieved from Academic Search Premier database 
Elvebakk, B. (2008). Philosophy Democratized? A comparison between Wikipedia and two other web-based philosophy resources. First Monday, 13(2). Retrieved from http://www.uic.edu/htbin/cgiwrap/bin/ojs/index.php/fm/article/view/2091/1938

Encyclopaedia of Philosophy of Education. (2010). M. A. Peters, P. Ghiraldelli, B. Zarnic, A. Gibbons \& R. Heraud (Eds.), Retrieved from http://www.vusst.hr/ENCYCLOPAEDIA/doku.php

Garfield, E. (1996). When to cite. Library Quarterly, 66(4), 449-458. Retrieved from http://www.jstor.org/stable/4309157

Gilbert, G. N. (1977). Referencing as persuasion. Social Studies of Science, 7(1), 113-122. Retrieved from http://www.jstor.org/stable/284636

GNU operating system. (2009). 2009(8 December). Retrieved from http://www.gnu.org/licenses/fdl.html\#header

Gorman, G. (2007). A tale of information ethics and encyclopaedias: or, is Wikipedia just another internet scam? Online Information Review, 31(3), 273-276. Retrieved from www.emeraldinsight.com/1468-4527.htm

Hammer, E., \& Zalta, E. (1997). A solution to the problem of updating encyclopedias. Computers and the Humanities, 31(1), 47-60. Retrieved from SpringerLink database

Harwood, N. (2008). Citers' use of citees' names: Findings from a qualitative interview-based study. Journal of the American Society for Information Science and Technology, 59(6), 1007-1011. Retrieved from http://dx.doi.org/10.1002/asi.20789

Haycock, L. A. (2004). Citation analysis of education dissertations for collection development. Library Resources and Technical Services, 48(2), 102-106. Retrieved from Library Literature \& Information Science Full Text database

Hertzel, D. H. (2003). Bibliometrics History. Encyclopedia of Library and Information Science: Second Edition, 288 - 328. Retrieved from http://www.informaworld.com/10.1081/E-ELIS-120009034

Kaplan, N. (1965). The norms of citation behaviour: prolegomena to the footnote. American Documentation (pre-1986), 16(3), 179-184. Retrieved from doi:640595901

Kister, K. F. (1994). Kister's best encyclopedias: a comparative guide to general and specialized encyclopedias (2nd ed.). Phoenix, AZ: Oryx.

Knight-Davis, S., \& Sung, J. S. (2008). Analysis of citations in undergraduate papers. College \& Research Libraries, 69(5), 447-458. Retrieved from 
Kushkowski, J. D., Parsons, K. A., \& Wiese, W. H. (2003). Master's and doctoral thesis citations: Analysis and trends of a longitudinal study. Portal : Libraries and the Academy, 3(3), 459-479. Retrieved from ProQuest database

Kuyper-Rushing, L. (Mar 1999). Identifying uniform core journal titles for music libraries: A dissertation citation study. College \& Research Libraries, 60(2), 153-163. Retrieved from Library Literature and Information Full Text database

Lim, S. (2009). How and why do college students use Wikipedia? Journal of the American Society for Information Science and Technology, 60(11), 2189-2202. Retrieved from http://dx.doi.org/10.1002/asi.21142

Liu, Z. (1997). Citation theories in the framework of international flow of information: new evidence with translation analysis. Journal of the American Society for Information Science (1986-1998), 48(1), 80-87. Retrieved from http://proquest.umi.com/pqdweb?did $=639285351 \& \mathrm{Fmt}=7 \&$ clientld $=7511 \& R Q T=30$ 9\&VName=PQD

MacRoberts, M. H., \& MacRoberts, B. R. (1989). Problems of citation analysis: A critical review. Journal of the American Society for Information Science, 40(5), 342-349. Retrieved from ABI/INFORM Global database

Making of America. (2005). Encyclopaedia of missions. Descriptive, historical, biographical, statistical, with a full assortment of maps, a complete bibliography, and lists of Bible versions. E. M. Bliss (Ed.) Retrieved from http://name.umdl.umich.edu/AJG7411.0002.001

Maron, N. L., \& Smith, K. K. (2009). Current models of digital scholarly communication: Results of an investigation conducted by Ithaka Strategic Services for the Association of Research Libraries. Journal of Electronic Publishing, 12(1). Retrieved from http://dx.doi.org/10.3998/3336451.0012.105

Merton, R. K. (1968). The Matthew effect in science. Science, 159(3810), 53-63. Retrieved from http://www.jstor.org/stable/1723414

Moed, H. F. (2005). Citation analysis in research evaluation (electronic resource) Retrieved from http://dx.doi.org/10.1007/1-4020-3714-7

Nielsen, F. A. (2007). Scientific citations in Wikipedia. First Monday, 12(8). Retrieved from http://firstmonday.org/issues/issue12 8/nielsen/index.html

Old revisions. (2010). Encyclopaedia of philosophy of education, 2010( ). Retrieved from http://www.vusst.hr/ENCYCLOPAEDIA/doku.php?id=welcome\&do=revisions

Open-Site Foundation. (2009). Open-Site: Free internet encyclopedia Retrieved 8 December, 2009, from http://open-site.org/ 
Pack, T. (2004). Specialized encyclopedias for in-depth information. Information Today, 21(5), 29-30. Retrieved from WilsonWeb database

Pancheshnikov, Y. (2007). A comparison of literature citations in faculty publications and student theses as indicators of collection use and a background for collection management at a university library. Journal of Academic Librarianship, 33(2), 674683. Retrieved from Library Literature and Information Science Full Text database

Physorg. (March 30, 2009). Microsoft closing Encarta online encyclopedia. Physorg: Science: physics: tech: nano: news Retrieved 17 January, 2010, from http://www.physorg.com/news157661569.html

Prabha, C. G. (1983). Some aspects of citation behaviour: a pilot study in business administration. Journal of the American Society for Information Science, 34(3), 202206. Retrieved from ABI/INFORM Global database

Raven, J., \& Goldman, L. (2007). The Oxford dictionary of national biography. The Historical Journal, 50(4), 991-1006. Retrieved from http://dx.doi.org/10.1017/50018246×07006474

Rector, L. H. (2008). Comparison of Wikipedia and other encyclopedias for accuracy, breadth, and depth in historical articles. Reference Services Review, 36(1), 7-22. doi: 10.1108/00907320810851998

Royal, C., \& Kapila, D. (2009). What's on Wikipedia, and what's not...? Assessing completeness of information. Social Science Computer Review, 27(1), 138-148. doi: $10.1177 / 0894439308321890$

Santana, A., \& Woods, D. J. (2009a). Transparency and social responsibility issues for Wikipedia. Ethics and Information Technology, 11(2), 133-144. Retrieved from doi:10.1007/s10676-009-9193-y

Santana, A., \& Woods, D. J. (2009b). Transparency and social responsibility issues for Wikipedia. Ethics and Information Technology, 11(2), 133-144. doi: 10.1007/s10676009-9193-y

Schweitzer, N. J. (2008). Wikipedia and psychology: coverage of concepts and its use by undergraduate students. Teaching of Psychology, 35(2), 81-85. doi: 10.1080/00986280802004594

Sheldon, T. (2001). Encyclopedia of networking and telecommunications Retrieved 13 January, 2010, from http://www.linktionary.com/about.html

Svoboda, E. (2006). One-click content, no guarantees: Should you trust the world's first usergenerated encyclopedia? IEEE Spectrum, 43(5), 64-65. Retrieved from http://ieeexplore.ieee.org.helicon.vuw.ac.nz/stamp/stamp.jsp?tp=\&arnumber=1628

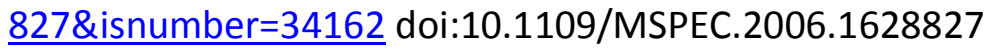


Te Ara. (1966). An encyclopaedia of New Zealand 1966 Retrieved 13 January, 2010, from http://www.teara.govt.nz/en/1966

Thorne, F. C. (1977). The citation index: Another case of spurious validity. Journal of Clinical Psychology, 33(4), 1157-1161. doi: 10.1002/1097-4679(197710)33:4<1157::AIDJCLP2270330453>3.0.CO;2-B

University of Auckland. (2009). ResearchSpace@Auckland. Retrieved 2 December 2009, from University of Auckland http://researchspace.auckland.ac.nz/

Van der Veer Martens, B., \& Goodrum, A. A. (2006). The diffusion of theories: a functional approach. Journal of the American Society for Information Science and Technology, 57(3), 330-341. Retrieved from doi:10.1002/asi.20285

Van Raan, A. F. J. (1998). In matters of quantitative studies of science the fault of theorists is offering too little and asking too much - Comments on theories of citation? Scientometrics, 43(1), 129-139. Retrieved from ISI Web of Knowledge database

Victoria University of Wellington. (2009, 6 July 2009). Library subscription review 2009 Retrieved 15 August \& 26 November, 2009, from http://library.vuw.ac.nz/blog/?p=93

Waters, N. L. (2007). Why you can't cite Wikipedia in my class. Communications of the ACM, 50(9), 15-17. Retrieved from

Waugh, C. K., \& Ruppel, M. (2004). Citation analysis of dissertation, thesis, and research paper references in workforce education and development. Journal of Academic Librarianship, 30(4), 276 - 284. Retrieved from Library Literature and Information Science Full Text database

Wikipedia Foundation. (2009). Wikipedia: the free encyclopedia Retrieved 8 December, 2009, from http://en.wikipedia.org/wiki/Main Page

Wikipedia tightens editing policy. (2009). InformationWeek. Retrieved from Expanded Acadamic ASAP. Gale.

Wiley-Blackwell. (1999). Encyclopedia of life sciences Retrieved 11 January, 2010, from http://www.els.net/default.asp

Yeap, C. K., \& Kiran, K. (2008). Citation study of library and information science dissertations for collection development. Malaysian Journal of Library and Information Science, 13(2), 29-47. Retrieved from 


\subsection{Bibliography}

Allen, B., Qin, J., \& Lancaster, F. W. (1994). Persuasive communities: A longitudinal analysis of references in the philosophical transactions of the Royal Society, 1665-1990. Social Studies of Science, 24(2), 279-310. Retrieved from http://www.jstor.org/stable/285433

Arunachalam, S. (1998). Citation analysis: Do we need a theory? Comments on theories of citation? Scientometrics, 43(1), 141-142. Retrieved from SpringerLink database

Badke, W. (2008). What to do with Wikipedia. Online, 32(2), 48-50. Retrieved from $\mathrm{ABI} / \mathrm{INFORM}$ Global database

Balaban, A. T., \& Randic, M. (2000). Proposal for using an untapped source of citations characterizing scientific areas. Scientometrics, 49(3), 517-521. Retrieved from SpringerLink database

Black, E. W. (2008). Wikipedia and academic peer review: Wikipedia as a recognised medium for scholarly production? Online Information Review, 32(1), 73-88. doi: 10.1108/14684520810865994

Bornmann, L., \& Daniel, H. (2008). What do citation counts measure? A review of studies on citing behaviour. [Literature review]. [Emerald]. Journal of Documentation, 64(1), 4580. doi: $10.1108 / 00220410810844150$

Bott, D. M., \& Hargens, L. L. (1991). Are sociologists' publications uncited? Citation rates of journal articles, chapters, and books. The American Sociologist, 22(2), 147--158. doi: 10.1007/BF02691874

Bourke, P., \& Butler, L. (1996). Publication types, citation rates and evaluation. Scientometrics, 37(3), 473-494. doi: 10.1007/BF02019259

Bowman, M. (1991). Format citation patterns and their implications for collection development in research libraries. Collection Building, 11(1), 2-8. Retrieved from Emerald database

Bryman, A. (2008). Social research methods (Third ed.). New York: Oxford University Press.

Collison, R. L. (1964). Encyclopaedias: their history throughout the ages. A bibliographic guide with extensive historical notes to the general encyclopaedias issued throughout the world from 350 B.C. to the present day. New York: Hafner.

Cronin, B., Snyder, H., \& Atkins, H. (1997). Comparative citation rankings of authors in monographic and journal literature: a study of sociology. Journal of Documentation, 53(3), 263-273. Retrieved from Emerald database

Cullars, J. (1989). Citation characteristics of French and German literary monographs. The Library Quarterly, 59(4), 305-325. Retrieved from http://www.jstor.org/stable/4308406 
Cullars, J. (1990). Citation Characteristics of Italian and Spanish literary monographs. The Library Quarterly, 60(4), 337-356. Retrieved from http://www.jstor.org/stable/4308510

Cyclopedia of New Zealand. (1897-1908). Vol. 1-6. Industrial, descriptive, historical, biographical, facts, figures, illustrations Retrieved from http://www.nzetc.org/tm/scholarly/tei-corpus-cyclopedia.html

Dennis, A. (2009). Mountains - mountains and New Zealand culture. Te Ara - the Encyclopedia of New Zealand. Retrieved from http://www.TeAra.govt.nz/en/mountains/6

Encyclopedia. (2009). Merriam-Webster online dictionary. Retrieved from http://www.merriam-webster.com/dictionary/encyclopedia 24 November 2009.

Garfield, E. (1964). "Science citation index"-A new dimension in indexing. Science, 144(3619), 649-654. Retrieved from New Series website: http://www.jstor.org/stable/1712875

Garfield, E. (1972). Citation analysis as a tool in journal evaluation. Science, 178(4060), 471479. Retrieved from New Series website: http://www.jstor.org/stable/1735096

Garfield, E. (1998). Random thoughts on citationology. Its theory and practice. Scientometrics, 43(1), 69-76. Retrieved from SpringerLink database

Haridasan, S., \& Khan, M. (2009). Impact and use of e-resources by social scientists in National Social Science Documentation Centre (NASSDOC), India. The Electronic Library, 27(1), 117-133. doi: 10.110802640470910934632

Harman, K., \& Koohang, A. (2006). Diffusion of selected concepts in information systems and management: 1973-2004. Industrial Management \& Data Systems, 106(5-6), 663679. doi: $10.1108 / 02635570610666430$

Herther, N. K. (2009). Research evaluation and citation analysis: key issues and implications. The Electronic Library, 27(3), 361-375. doi: 10.1108/02640470910966835

Hovde, K. (2000). Check the citation: library instruction and student paper bibliographies. Research Strategies, 17(1), 3-9. Retrieved from ScienceDirect database

Hovde, K. (2007). You can't get there from here: student citations in an ephemeral electronic environment. College \& Research Libraries, 68(4), 312 - 321. Retrieved from Library Literature and Information Science Full Text database

Huang M, \& Chang, Y. (2008). Characteristics of research output in social sciences and humanities: From a research evaluation perspective. Journal of the American Society for Information Science and Technology, 59(11), 1819-1828. doi: 10.1002/asi.20885

Jowitt, A. (2008). Perceptions and usage of library instructional podcasts by staff and students at New Zealand's Universal College of Learning (UCOL). Reference Services Review, 36(3), 312-336. Retrieved from doi: 10.1108/00907320810895396 
Kayvan Kousha, \& Mike Thelwall. (2009). Google book search: Citation analysis for social science and the humanities. Journal of the American Society for Information Science and Technology, 60(8), 1537-1549. doi: 10.1002/asi.21085

Kelland, J. L., \& Young, A. P. (1994). Citation as a form of library use. Collection Management, 19(1), 81-100. Retrieved from http://dx.doi.org/10.1300/J105v19n01_04

Kink, N., \& Hess, T. (2008). Search engines as substitutes for traditional information sources? An investigation of media choice. The Information Society, 24, 18-29. Retrieved from doi: 10.1080/01972240701771630

Kostoff, R. N. (1998). The use and misuse of citation analysis in research evaluation comments on theories of citation? Scientometrics, 43(1), 27-43. Retrieved from <Go to $|S|>: / /$ WOS:000075877700003

Kriebel, L., \& Lapham, L. (2008). Transition to electronic resources in undergraduate social science research: a study of honors theses bibliographies, 1999-2005. College \& Research Libraries, 69(3), 268-283. Retrieved from Library Literature and Information Science Full Text database

Lariviere, V., \& Gingras, Y. (2009). The impact factor's Matthew Effect: A natural experiment in bibliometrics. Journal of the American Society for Information Science and Technology. doi: 10.1002/asi.21232

Leiding, R. (2005). Using citation checking of undergraduate honors thesis bibliographies to evaluate library collections. College \& Research Libraries, 66(5), 417-429. Retrieved from Library Literature and Information Science Full Text database

Leydesdorff, L. (1998). Theories of citation? Scientometrics, 43(1), 5-25. Retrieved from SpringerLink Contemporary database

Leydesdorff, L., \& Wouters, P. (1999). Between texts and contexts: advances in theories of citation? (A rejoinder). Scientometrics, 44(2), 169-182. Retrieved from SpringerLink database

Liu, M. (1993). Progress in documentation. The complexities of citation practice: A review of citation studies. Journal of Documentation, 49(4), 370-408. Retrieved from Emerald database

Makino, J. (1998). Productivity of research groups - Relation between citation analysis and reputation within research communities - Comments on theories of citation? Scientometrics, 43(1), 87-93. Retrieved from SpringerLink database

Martens, B. V. D., \& Goodrum, A. A. (2006). The diffusion of theories: A functional approach. Journal of the American Society for Information Science and Technology, 57(3), 330341. doi: 10.1002/asi.20285

Marx, Karl: impact on sociology. (2008). Vol. 4. In William A Darity Jr (Ed.) International Encyclopedia of the Social Sciences (pp. 635-638). Retrieved from Gale Virtual Reference Library database 
Maunch, J. E., \& Park, N. (2003). Appendix A: Suggested proposal and project guidelines. Guide to the successful thesis and dissertation: a handbook for students and faculty. (5th ed., pp. 303-308). New York: Marcel Dekker.

Moed, H. F., \& Garfield, E. (2004). In basic science the percentage of 'authoritative' references decreases as bibliographies become shorter. Scientometrics, 60(3), 295303. Retrieved from SpringerLink database

Nalimov, V. V. (Nov, 1987). Scientists are not acrobats. Scientometrics, 12(5-6), 303-304. Retrieved from SpringerLink database

Olesko, K. (n.d.). Disciplines. In J. L. Heilbron (Ed.) The Oxford companion to the history of modern science. Retrieved from Oxford Reference Online database http://www.oxfordreference.com/views/ENTRY.html?subview=Main\&entry=t124.e0 190

Phelan, T. J. (1999). A compendium of issues for citation analysis. Scientometrics, 45(1), 117136. Retrieved from SpringerLink database

Pichappan, P., \& Sarasvady, S. (2002). The other side of the coin: The intricacies of author self-citations. Scientometrics, 54(2), 285-290. Retrieved from SpringerLink database

Shadish, W. R., Tolliver, D., Gray, M., \& Gupta, S. K. S. (1995). Author judgements about works they cite: Three studies from psychology Journals. Social Studies of Science, 25(3), 477-498. Retrieved from http://www.jstor.org/stable/285503

Simpson, I. S. (1990). How to interpret statistical data: a guide for librarians and information scientists. London: Library Association.

Small, H. (2004). On the shoulders of Robert Merton: Towards a normative theory of citation. Scientometrics, 60(1), 71-79. Retrieved from ISI Web of Knowledge database

Smith, L. C. (1981). Citation analysis. Library Trends, 30, 83-106.

Sook Lim. (2009). How and why do college students use Wikipedia? Journal of the American Society for Information Science and Technology, 9999(9999), 1-14. Retrieved from http://dx.doi.org/10.1002/asi.21142

Soper, M. E. (1976). Characteristics and use of personal collections. The Library Quarterly, 46(4), 397-415. Retrieved from http://www.jstor.org/stable/4306719

Sproull, N. L. (1995). Handbook of research methods: a guide for practitioners and students in the social sciences (2nd ed.). Metuchen, N. J. : Scarecrow Press.

Stewart, J. A. (1983). Achievement and ascriptive processes in the recognition of scientific articles. Social Forces, 62(2), 166-189. Retrieved from Academic Search Premier database

Sylvia, M. J. (1998). Citation analysis as an unobtrusive method for journal collection evaluation using psychology student research bibliographies. Collection Building, 17(1), 20-28. Retrieved from Emerald database 
Tang, R. (2008). Citation characteristics and intellectual acceptance of scholarly monographs. College \& Research Libraries, 69(4), 356-369. Retrieved from HW Wilson database

University. (2005). In C. Soanes \& A. Stevenson (Eds.), The Oxford Dictionary of English Retrieved from Oxford Reference Online database 24 November 2009.

University. (n.d.). WordNet Search 3.0. Retrieved 24 November 2009, from http://wordnetweb.princeton.edu/perl/webwn?s=university

Victoria University of Wellington. (2009, 5 December 2007). Encyclopedias. Online reference collection. Retrieved 15 August, 2009, from http://www.victoria.ac.nz/library/research/reference/encyclopedias.aspx

Victoria University of Wellington Library. (2009). Engineering. Retrieved 29 September, 2009, from http://www.victoria.ac.nz/library/subjectguides/engineering/reference.aspx

Victoria University of Wellington Library. (2009). Political science and international relations: reference sources. Retrieved 29 September, 2009, from http://www.victoria.ac.nz/library/subjectguides/politicalscience/reference.aspx

Victoria University of Wellington Library. (2009). Sociology and social policy. Retrieved 29 September 2009, from http://www.victoria.ac.nz/library/subjectguides/sociology/reference.aspx

Vinkler, P. (1998). Comparative investigation of frequency and strength of motives toward referencing, the reference threshold model - Comments on theories of citation? Scientometrics, 43(1), 107-127. Retrieved from ISI Web of Knowledge database

Wallin, J. A. (2005). Bibliometric methods: pitfalls and possibilities. Basic \& Clinical Pharmacology \& Toxicology, 97(5), 261-275. doi: 10.1111/j.17427843.2005.pto_139.x

Wu, M. M. (2005). Why print and electronic resources are essential to the academic law library. Law Library Journal, 97(2), 233-256. Retrieved from Library Literature and Information Science Full Text database

Yeoh, K. H., \& Kaur, K. (2008). Subject support in collection development: using the bibliometric tool. . Collection Building, 27(4), 157-166. doi: 10.1108/01604950810913724

Yu, F., Sullivan, J., \& Woodall, L. (2006). What can students' bibliographies tell us? Evidence based information skills teaching for engineering students. Evidence Based Library and Information Practice, 2(2), 12-22. Retrieved from http://ejournals.library.ualberta.ca/index.php/EBLIP/article/view/8/123 
Word Count: 11,963 